\title{
Caveolae: biochemical analysis
}

\author{
Christian Chatenay-Rivauday*, Z. Petek Cakar**, Paul Jenö, Elena S. Kuzmenko*** \& \\ Klaus Fiedler**** \\ Division of Biochemistry, Biozentrum, University of Basel, Klingelbergstrasse 70, CH-4056 Basel, Switzer- \\ land; *Current addresses: Novartis Ophtalmics, Research, CH-4002 Basel, Switzerland; **Department of \\ Molecular Biology and Genetics, Istanbul Technical University, T-80626 Maslak, Turkey; **** Pediatric Surgery, \\ Kantonsspital Basel, CH-4031 Basel, Switzerland; ****Author for correspondence (Phone/Fax 41-61-3211395; \\ E-mail: $\left.k \_f i e d l e r @ b l u e w i n . c h\right)$
}

Accepted 17 September 2003

Key words: plasmalemmal vesicle, mechanosignaling, membrane potential, endothelia, compliance

\begin{abstract}
Caveolae appear in a multitude of processes encompassing growth regulation and trafficking. We demonstrate the abundant presence of ESA/reggie-1/flotillin-2, ATP synthase $\beta$ subunit and annexin V in endothelial caveolae by immunopurification of caveolae from vascular endothelial membrane. Five proteins are abundant in a caveolin1 protein complex, analyzed by sucrose gradient velocity sedimentation following octyl- $\beta$-D-glucopyranoside extraction. Caveolin-1 $\alpha$ interacts with caveolin-1 $\beta$, caveolin-2, actin, the microsomal form of NADH cytochrome B5 reductase and ESA/reggie-1/flotillin-2 as shown by co-immunoprecipitation. We propose the concept that ATP biosynthesis in caveolae regulates mechanosignaling and is induced by membrane depolarization and a proton gradient. Pressure stimuli and metabolic changes may trigger gene regulation in endothelial cells, involving a nuclear conformer of caveolin-1, shown here with an epitope-specific caveolin-1 antibody, and immediate response of ion channel activity, regulated by ESA/reggie-1/flotillin-2.
\end{abstract}

\section{Introduction}

Blood vessels constrict upon innervation and autonomously in orthostatic changes, which increase the hydrostatic pressure in the vascular system [1] (but see [2]). The heartbeat regulates systemic blood flow by adjusting the frequency and output and constriction of vessels contributes to local regulation. Nitric oxide (NO) is tonically produced in caveolae by endothelial NO synthase (eNOS) to balance vessel tonus and dilates the vessels $[3,4]$. Caveolae have been implicated in general mechanotransduction upon shear flow, are increased in number upon laminar shear exposure and are relocated during migration in living cells [58]. Caveolae from endothelia have been studied by western blotting of immunoisolated membranes. They were shown to contain thrombomodulin, functional thrombin receptor, $\mathrm{G}$ protein $\alpha_{\mathrm{q}}$ and endothelial nitric oxide synthase [9-11]. The stoichiometry of proteins, however, interacting with caveolin and composition of endothelial caveolae, as distinct from lipid rafts in general [12], has not yet been determined.

The process of mechanotransduction is likely connected to compliance modulation and it is indicative, that vascular abnormalities are found in caveolin-1 null mice $[13,14]$. The recent immunopurification of caveolae from adipocytes, however, shows that SSAO, an extracellular amine oxidase that might modulate lipolysis, and CD36, a scavenger receptor, are major components [15]. In addition it has been found, that cardiac caveolae contain a significant fraction of $\mathrm{Na}^{+} / \mathrm{K}^{+}$-ATPase implicated in maintaining a membrane potential [16]. It is suggested to stimulate exchange of calcium by the $\mathrm{Na}^{+} / \mathrm{Ca}^{2+}$-exchanger, previously shown to associate with caveolin-3 and to be involved in regulation of endothelial nitric-oxide synthase [17, 18]. If this composition were generally found for caveolae of all types of cells, one could 


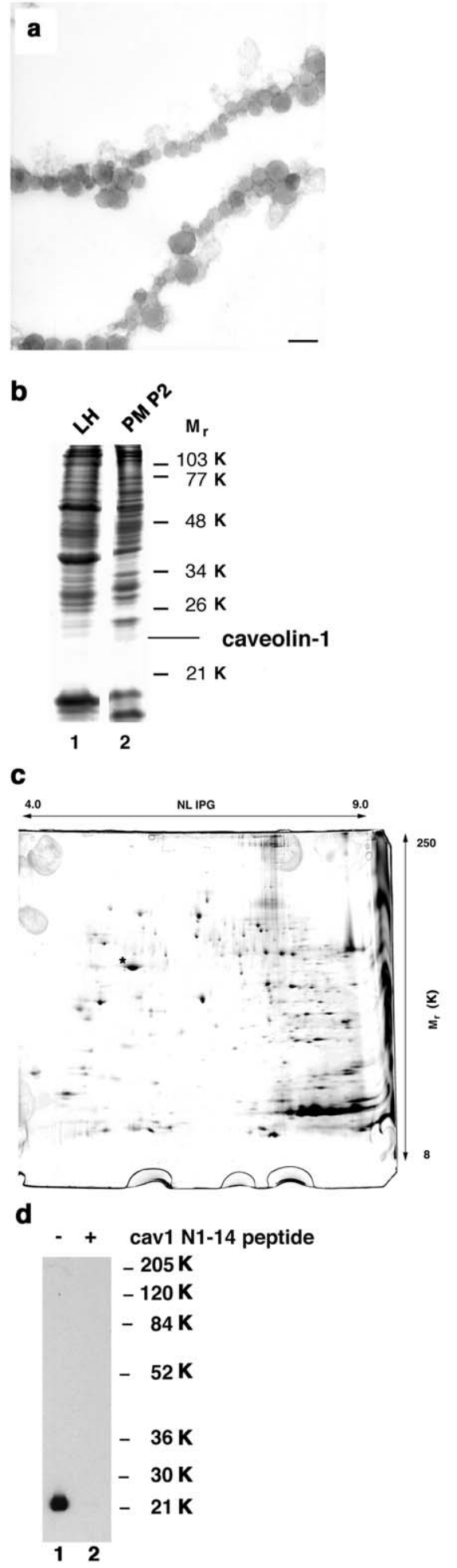

e

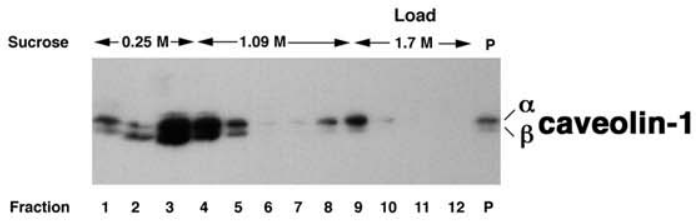

f

caveolae

Beads Supernatant

cav1-N14

$\begin{array}{llll}+ & + & + & + \\ + & - & + & -\end{array}$

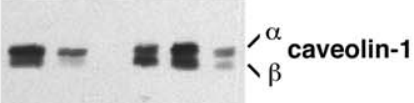

$\begin{array}{lllll}1 & 2 & 3 & 4 & 5\end{array}$

g

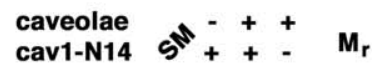

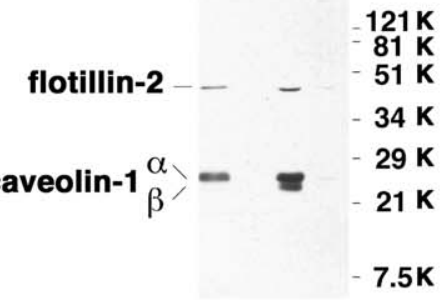

$\begin{array}{llll}1 & 2 & 3 & 4\end{array}$

h
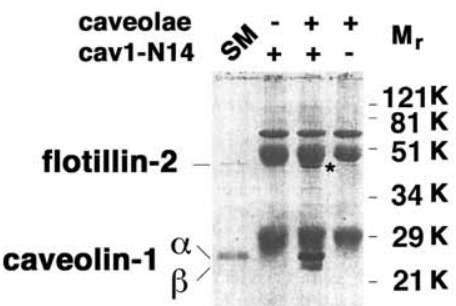

$\begin{array}{llll}12 & 34\end{array}$

$7.5 \mathrm{~K}$
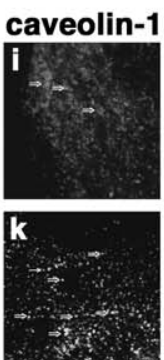

Zoom 
Figure 1. Caveolae immunoisolation. All experiments in panels a-h were carried out with membranes isolated from rat lung endothelia by colloidal silica perfusion. (a) Electron microscopy of P1 membranes. Luminal endothelial plasma membrane adheres to the silica particles (average size $50 \mathrm{~nm}$ ), caveolae are visible as protruding structures. Bar $50 \mathrm{~nm}$. (b) Protein composition of endothelial plasma membrane. The lung homogenate (LH, $100 \mu \mathrm{g}$, lane 1) and P2 membranes (PM P2, $75 \mu \mathrm{g}$, lane 2) obtained by the silica perfusion method were analyzed by $14 \%$ SDS-PAGE and Coomassie blue staining of gels. The identity of caveolin-1 was confirmed by western blotting with caveolin-1 polyclonal antibodies (not shown). Molecular weight markers are indicated. (c) Protein composition of endothelial plasma membrane. $100 \mu \mathrm{g}$ of P1 membranes were resolved on two-dimensional gels by isoelectric focussing. The sample was solubilized in loading buffer and the supernatant (in the absence of silica beads) was resolved on non-linear 3.5-10 immobilized pH gradient (IPG) focussing strips. Proteins were visualized by silver-staining. (d) Specificity of the cav1N14 antibody. $7.5 \mu \mathrm{g}$ of P1 membranes were resolved by $12 \%$ SDS-PAGE and incubated with affinity-purified cav1N14 antibodies in the absence (lane 1) or presence (lane 2) of excess of the antigen. The blot was developed by enhanced chemiluminescence. (e) Subcellular fractionation. For immunoisolation P1 membranes were sonicated, adjusted to $1.7 \mathrm{M}$ sucrose and fractionated on a $0.25 \mathrm{M} / 1.09 \mathrm{M}$ two-step sucrose flotation gradient. A sample of the gradient fractions was resolved by $14 \%$ SDS-PAGE, caveolin-1 $\alpha$ and $\beta$ was visualized by western blotting with caveolin-1 polyclonal antibodies and enhanced chemiluminescence. (f) Immunoisolation. $40 \mu \mathrm{g}$ of caveolin-enriched membranes (derived from pooled fractions 2-4; panel e) were incubated with immunobeads pre-adsorbed with (lane 1) or without (lane 2) affinity-purified cav1N14 antibodies. Bound (lanes 1,2) and unbound membranes (lanes 3,4) were analyzed by $14 \%$ SDS-PAGE. $2 \mu \mathrm{g}$ of the starting material (SM) is shown in lane 5. Nitrocellulose blots were developed by enhanced chemiluminescence and quantified by densitometry. (g)-(h) Immunoisolation from an independent experiment. Equal amounts of light membranes corresponding to fractions 2-4 (panel e) were incubated with (lanes 3) or without (lanes 4) affinity-purified cav1N14 antibodies and retrieved with immunobeads. The antibody alone $(6 \mu \mathrm{g})$ was incubated as control (lanes 2). Samples were resolved by 14\% SDS-PAGE. 1/10 of the starting material (SM) is shown in lanes 1. The nitrocellulose blot (panel h) was incubated with the ESA/reggie-1/flotillin-2 monoclonal and caveolin-1 polyclonal antibody and developed by enhanced chemiluminescence. The nitrocellulose blot stained with Ponceau $\mathrm{S}$ is shown in panel h. ESA/reggie-1/flotillin-2, caveolin-1 $\alpha$ and $\beta$ and molecular weight markers are indicated. (i)-(1) Localization of caveolin-1 and ESA/reggie-1/flotillin-2 in calf pulmonary artery endothelial (CPAE) cells. Cells were viewed and photographed with a confocal microsocope. Caveolin-1 $\alpha$ was visualized with caveolin-1 antibodies and secondary fluorescein conjugated antibodies (i, k). ESA/reggie-1/flotillin-2 was simultaneously detected with monoclonal ESA/reggie-1/flotillin-2 antibodies and secondary Cy3 antibodies (j, 1). Singly labeled spots are indicated with $\rightarrow$, double labeled areas and spots are indicated with $\Rightarrow$. Picture sizes: $100 \times 100 \mu \mathrm{m}$ top row, zoom $25 \times 25 \mu \mathrm{m}$ bottom row.

surmise that caveolae are involved in integration of ion fluxes [19] that, similar to synaptic vesicle release, leads to a physiological response.

Along another line, caveolae are proposed to be trafficking organelles, but the function of caveolin-1 and -2 in vesicular transport is controversial and the proteins have been suggested to be internalized seldom, similar to junctional factors [20-22]. Caveolae can be exploited in pathogen uptake [23], and although this organelle might show a remarkable plasticity, evident e.g. for related caveolin-3 in muscle [24], the most coherent explanation is that the dynamics of the cell contributes to many roles.

Mechanotransduction triggers intracellular signaling $[25,26]$. The lipid bilayer is stabilized by cytoskeletal attachment and receives shear forces and pressure stimuli. In vitro results suggest that pressure is integrated in bilayer mechanics and ion channel conductance. Membranes depolarize upon deformation from their resting potential by ion fluxes. The ion channel activity is affected by various interactions ranging from protein-protein, ionic to oxygen and enzymatic modification. Ion channels are proposed to link the extracellular matrix and the cytoskeleton and deflection of shear force triggers channel response [27-31]. At the same time, bilayer fluidity is altered in effective mechanosignaling [32] (see also [33]). Pressure regulates cell growth, impacts on the transcriptional repertoire [25], and affects chromatin structure (shear stress) [34].

The modularity which pertains to membrane signaling and organization also prevails for the location of biochemical reactions previously thought to be restricted to the mitochondrium. ATP biosynthesis in the exoplasm is a new phenomenon of unknown role shown in endothelia [35]. It involves mitochondrial ATP synthase encoded in the nuclear genome as open reading frames or as pseudogenes [36, 37], which may be expressed $[38,39]$; the enzyme is alternatively targeted to the plasma membrane [35, 40, 41]. Extracellular ATP is a ligand for purinergic receptors [42], kinases and possibly other enzymes [43] and generally is found extracellular upon mechanical stimulation of cells $[42,44]$. Although in this role, ATP release from endothelia upon shear stress was suggested to occur by a vesicular mechanism [45] and chromaffin granule import of ions and ATP for neurosecretion has been demonstrated [46], the question remains how extracellular ATP generally is set free. This might relate to the integration functions of caveolae in signaling, and not to ion homeostasis, as previously proposed [47].

We now show that the composition of caveolae is simple with ESA/reggie-1/flotillin-2, previously analyzed [48-51], as one of the major components in addition to ATP synthase and annexin V. ESA/reggie1/flotillin-2 homologues are implicated in ion chan- 
nel regulation and provide DEG channel coactivity $[26,52]$. Caveolae may thus fulfil functions in mechanosignaling by ion channel regulation and ATP synthesis/hydrolysis.

\section{Results and discussion}

\section{Caveolae immunoisolation}

Plasma membranes, isolated from rat lungs, were visualized by electron microscopy and showed silica particles with protrusions of membrane and caveolae (Figure 1a). These membranes were previously labeled with caveolin-1 antibodies demonstrating the abundance and presence of caveolae [9]. In lung homogenate caveolin-1 was enriched in the plasma membrane preparation (Figure 1b) as visualized by SDSPAGE (and western overlay). To analyze the complexity of the protein composition, the membrane isolate was resolved by two-dimensional (2D) immobilized $\mathrm{pH}$ gradient (IPG) SDS-PAGE. One major silverstained spot (Figure 1c) corresponded to $\beta / \gamma$ actin, the other proteins could not be compared directly to standard 2D-IPG-SDS-PAGE databases. The further analysis resulted in the identification of a $50 \mathrm{kDa}$ protein as a substoichiometric but second most abundant protein of the caveolae preparation. To the aim of biochemical analysis, antibodies were raised against the cav1N14 peptide and specificity was demonstrated by western blotting (Figure 1d). Membranes were released from the silica particles by sonication to harvest a light membrane fraction. Beads were overlaid with sucrose solution and centrifuged to float light membranes (Figure 1e). The majority of caveolin-1 containing membranes was present in fractions 2-4 of the gradient corresponding to a sucrose density of less than $1.14 \mathrm{~g} / \mathrm{cm}^{3}$. These light membranes were used for all subsequent experimental procedures. It is of note, that the light membranes (fractions 2-4) corresponded to only $0.03 \%$ of total lung homogenate protein (filtered) and to $3 \%$ of the starting P1 plasma membrane pellet.

In the analytical series, a small amount of fractions 2-4 (Figure 1e) was employed to demonstrate immunoisolation yield and efficiency. Membrane isolates (Figure 1f, $\mathrm{g}, \mathrm{h}$ ) and supernatants of the binding reaction (Figure 1f) were analyzed by SDS-PAGE and showed a major band migrating at approximately $50 \mathrm{kDa}$. This was visualized on a Ponceau $\mathrm{S}$ stained nitrocellulose blot and by western blotting
(Figure 1h). Caveolin-1 $\alpha$ and $\beta$ were the major proteins in addition to the $50 \mathrm{kDa}$ band. For technical reasons equal quantities of antibodies were resolved (Figure 1g, h, lanes 2) to allow the comparison of proteins shown of the unspecific and specific binding reaction with the antibody preparation only. The specifically isolated $50 \mathrm{kDa}$ protein migrating beneath the IgG heavy chain (Figure $1 \mathrm{~h}$ ) corresponded to ESA/reggie-1/flotillin-2 [48-50] as analyzed by the western overlay (Figure 1g). The $42 \mathrm{kDa}$ protein considered to be ESA/reggie-1/flotillin-2 [48, 49] is of $48 \mathrm{kDa}$ calculated molecular weight in rat [50, 53]. Densitometric quantification of this blot indicated that ESA/reggie-1/flotillin-2 was 1.4-fold depleted in the immunoisolate relative to caveolin-1, and suggested that although it is a major protein, it is also localized to endothelial membrane areas not containing caveolin-1. Consistently, confocal sections demonstrated a punctate distribution of caveolin-1 in calf pulmonary artery, large vessel endothelial (CPAE) cells (Figure 1i, k) coinciding with ESA/reggie-1/flotillin2 positive structures (Figure 1j, 1). Caveolin-1 labeled structures were mostly ESA/reggie-1/flotillin-2 positive but not vice versa.

\section{Actin in mechanosignaling}

The cytoskeleton is implicated in providing mechanical stability, tethering and adhesion in mechanotransduction. We find that actin localized at caveolae in microvascular SVEC4-10 mouse endothelial cells as analyzed by confocal immunofluorescence microscopy (Figure 2a-d). Actin distribution was patchy and bundles were absent in these cells. In contrast, in CPAE cells (and SVEC4-10 cells; data not shown) treated with the actin binding drug jasplakinolide [54] F-actin aggregates containing bundles and formed $d e$ novo, were labeled with caveolin-1 polyclonal antibodies. This was visualized by conventional (Figure 2e-h) and confocal microscopy (Figure 2g-l). Actin bundles (Figure $2 \mathrm{~h}, 1$ ) were proximal to caveolae and triggered their accumulation (Figure $2 \mathrm{~g}$, k) at or within these cortical areas. Filamin, which was previously shown to interact with caveolin-1, may provide a tether of caveolae to the cortical actin bundles [55]. In contrast to the previous observations in epithelia [56] the caveolin-1 localization close to the nucleus here coincided with dense actin structures (Figure 2j), which with respect to actin seems to be a specialization of endothelia. 


\section{ATP-driven turnover in complexes of caveolin}

We carried out a sucrose gradient velocity sedimentation experiment with octylglucopyranoside extracts of the membrane preparation seen in Figure 1c. The protein composition was simple with only five major proteins sedimenting in the $19 \mathrm{~S}$ area (Figure $2 \mathrm{~m}$ ). The presence of caveolin-1 and actin was determined by western blotting. The majority of caveolin-1 migrated in the $7.4 \mathrm{~S}$ area of the sucrose gradient and overlapped with the actin distribution (Figure $2 \mathrm{~m}$, lanes 4-6). Similar to some previous analyses [57, 58] the extract harbors a large quantity of small caveolin-1 complexes. But the large, high molecular weight caveolin-1 complex was originally assumed to only contain caveolin-1 [59], but this does not seem to be the case (Figure $2 \mathrm{~m}$ ) and is consistent with recent findings on heterooligomers of caveolin and ESA/reggie/flotillin proteins (see below) [60]. Detailed inspection of the sedimentation profile after ATP incubation added during extraction (Figure 2n), showed that the 7.4 $\mathrm{S}$ complex was shifting to a larger position (lanes 6,7). Actin sedimented with largely overlapping profile without ATP (Figure $2 \mathrm{~m}$ ) and was then dissociated (Figure $2 \mathrm{n}$ ). This result suggests that kinases and phosphatases are involved in modulating caveolin-1 oligomerization and/or interactions, as expected from differential localization of phosphorylated and non-phosphorylated forms [57]. We also find that caveolin-1 preferentially interacts with monomeric phosphorylated actin in coimmunoprecipitation experiments (data not shown).

\section{ATP synthase and annexin $V$}

To allow microsequencing of caveolae components, we resolved caveolae immunoisolates on 2D-IPGSDS-PAGE. To this aim, the residual of the experiment shown in Figure 1e (fractions 2-4) was used for a scaled-up immunoisolation reaction. $20 \mu \mathrm{g}$ of starting material is shown in panel a (Figure 3) stained with a highly sensitive silver impregnation protocol, demonstrating that the composition of the light membrane fraction was complex and actin was one of the major components (labeled with an asterik). ESA/reggie1/flotillin-2 and caveolin-1 were only detected on these gels by western blotting since they were smeared across the entire $\mathrm{pI}$ range (data not shown). Resolution of the immunoisolated material on 2D gels showed a distinct pattern of proteins of unspecifically bound (panel b), specifically bound membranes (panel c), and antibody incubate (panel d). On shrunken gels of the immunoisolate, a faint silver-stained partial accumulation of caveolin-1 in two spots was visible. Seven more proteins were not present in panels $b$ and $d$, but were discernible in panel c (specifically bound). These corresponded to factors of $56 \mathrm{kDa}$, three proteins of approximately $42 \mathrm{kDa}$, one protein of $36 \mathrm{kDa}$, factors of $25 \mathrm{kDa}$, and $12 \mathrm{kDa}$ apparent molecular weight. By apparent molecular weight and pI, the $42 \mathrm{kDa}$ proteins could correspond to trimeric $\mathrm{G}$ protein $\alpha$ subunits [11]. Tandem mass spectrometric analysis yielded five peptides for the $56 \mathrm{kDa}$ protein (1, Figure 3 ) corresponding in sequence to rat ATP synthase $\beta$ subunit. Five peptide sequences were obtained for the $36 \mathrm{kDa}$ spot which matched rat annexin $\mathrm{V}$ [61] (2, Figure 3). Calculated molecular weight and pI of these proteins corresponded to their migration on the $2 \mathrm{D}$ gels. Database searches in the rat genome indicated that the identified peptides of ATP synthase $\beta$ subunit and annexin $\mathrm{V}$ could be assigned to a unique gene.

Mitochondrial ATP synthase $\alpha$ and $\beta$ subunits have previously been shown to be targeted to the endothelial cell surface [35, 40], whereas the $\alpha$ subunit was present at the hepatic plasma membrane where this enzyme hydrolyzed ATP [41]. We conclude that mitochondrial ATP synthase is alternatively targeted to plasma membrane caveolae and the $\beta$ subunit is thus detected in the immunoisolate. Annexin V was shown to function as an ion channel in liposome preparations [61] but its cellular function has not been clarified at the mechanistic level and could include anoikis [62-64]. We conclude that the presence of annexin $\mathrm{V}$ may indicate a role of caveolae in calcium influx.

\section{NADH cytochrome $B 5$ reductase}

We set out to analyze the identity of caveolin-1 interacting factors on silver-stained one-dimensional SDS polyacrylamide gels by tandem mass spectroscopy. The preparative immunoprecipitation (Figure 4, lane 1) was carried out with octylglucopyranoside detergent extract of $12 \mathrm{mg}$ of plasma membrane with affinity-purified cav1N14 antibodies in a large scale preparation of rat lung luminal endothelial membrane. Extracts were incubated with cav1N14 affinitypurified antibodies to retrieve the caveolin- $1 \alpha$ complex (lane 3 ). Twelve proteins were specifically coimmunoprecipitated and were not visible in the control reaction including excess of antigenic peptide cav1N14 (lane 4) or antibodies only (lane 5). One protein migrating at $68 \mathrm{kDa}$ was considered to be a 

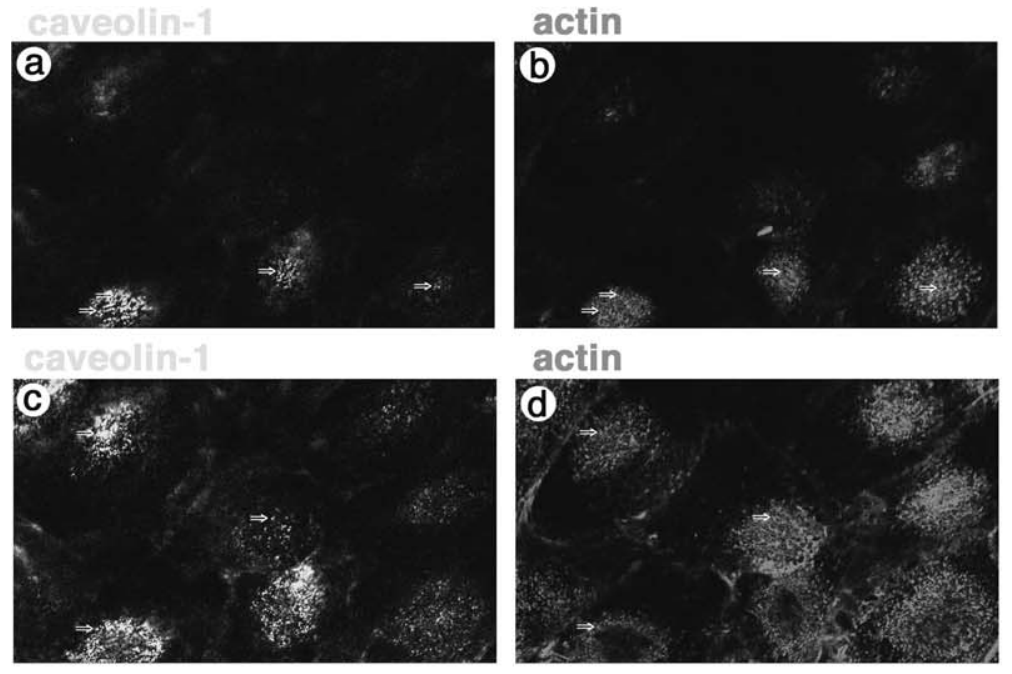

actin
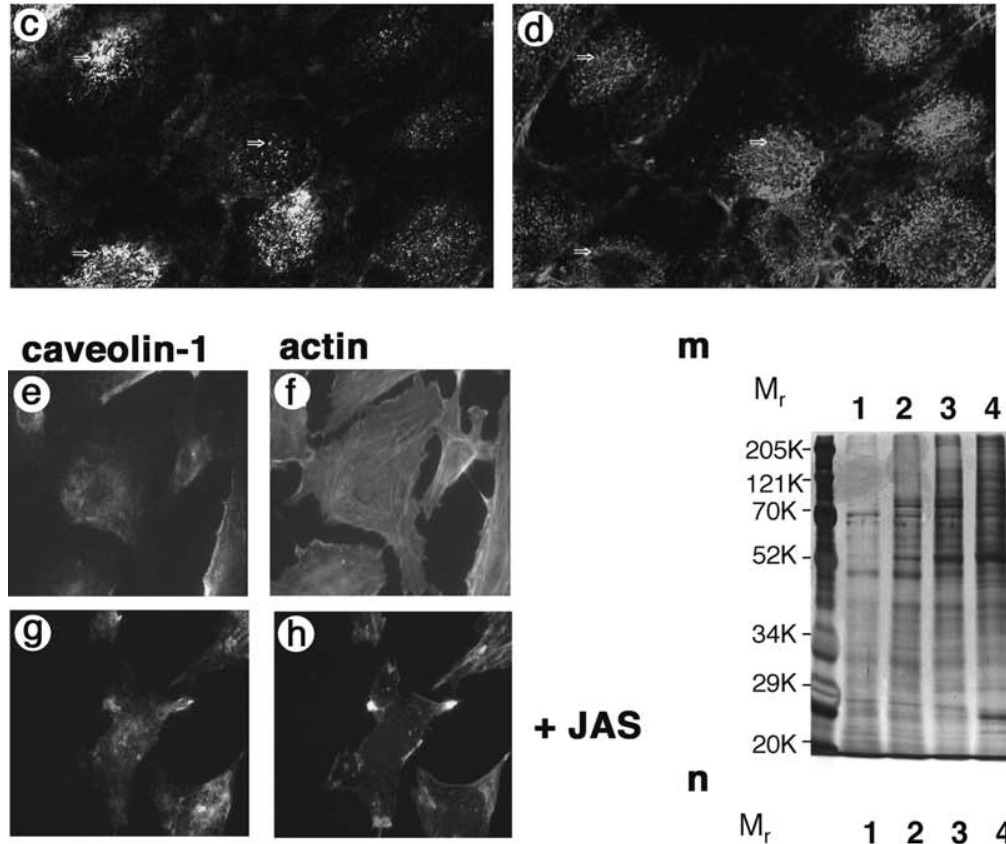

caveolin-1

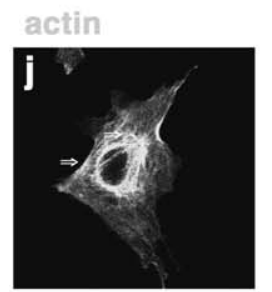

m
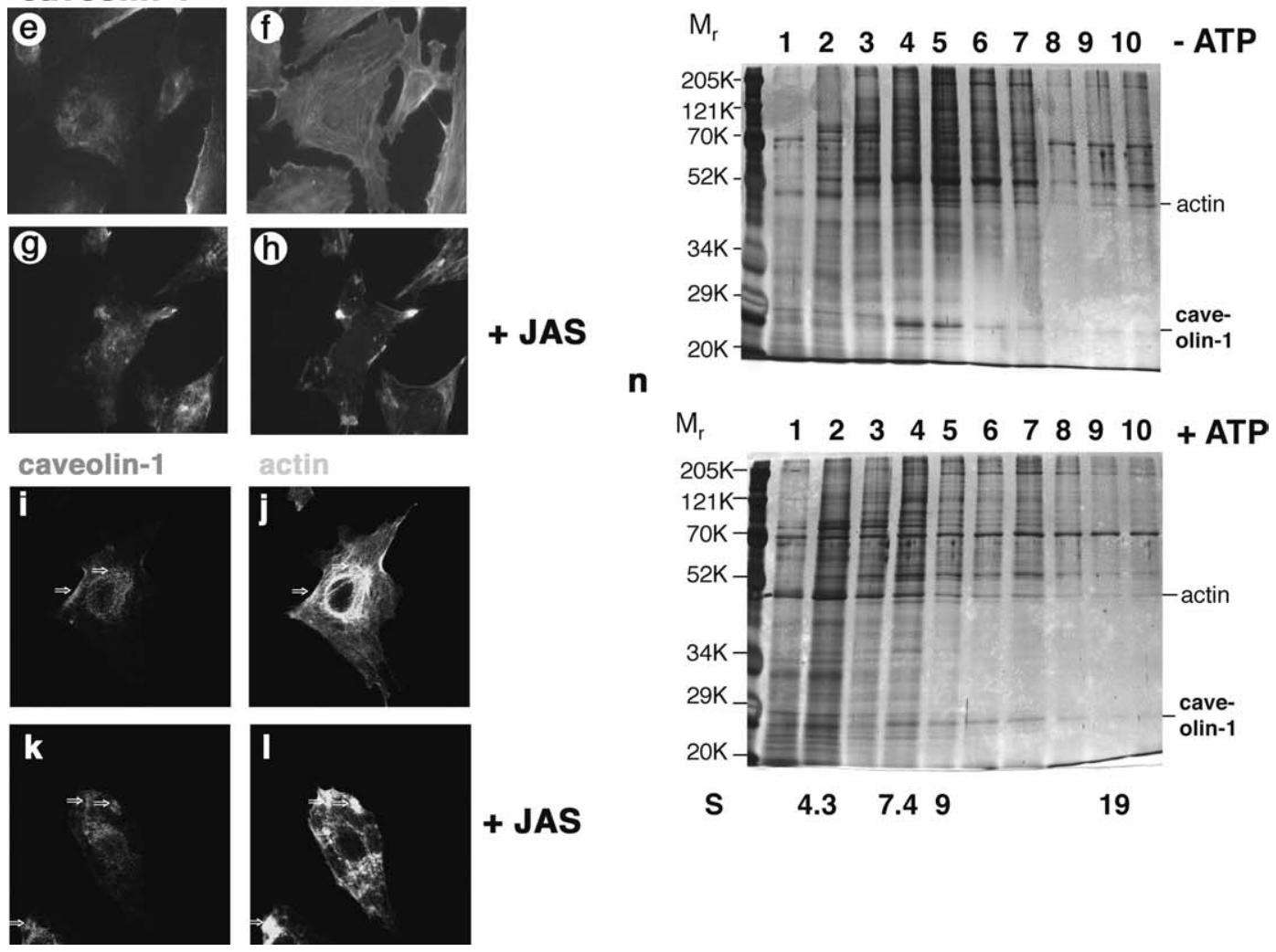

$\begin{array}{lll}\mathrm{S} & 4.3 \quad 7.49\end{array}$ 
Figure 2. Caveolin - actin localization in endothelial cells and sedimentation of caveolin complexes. (a)-(d) Confocal microscopy of caveolin-1 and actin in SVEC4-10 cells. The brightest double labeled spots are indicated with $\Rightarrow$. Cells were grown to confluence on coverslips. Caveolin-1 was visualized with caveolin-1 polyclonal antibodies and secondary fluorescein conjugated antibodies and actin was detected with monoclonal actin antibodies and secondary Cy3 conjugated antibodies. Two sections at the apical side of cells are shown, distance $0.4 \mu \mathrm{m}$. (e)-(h) Localization of caveolin-1 and actin in CPA endothelial cells analyzed by immunofluorescence microscopy. Caveolin-1 was visualized with caveolin-1 polyclonal antibodies and secondary fluorescein conjugated antibodies (e, g) and actin was detected with monoclonal actin antibodies and secondary Cy3 conjugated antibodies (f, h). Cells in $\left(\mathrm{g}, \mathrm{h}\right.$ ) were treated with $200 \mathrm{~nm}$ jasplakinolide for 60 min at $37{ }^{\circ} \mathrm{C}$. (i)-(l) Confocal microscopy of caveolin-1 and actin localization in CPA endothelial cells. Cells were incubated with guanidinium hydrochloride before immunofluorescence treatment. Caveolin-1 was visualized with affinity-purified cav1N14 antibodies and secondary rhodamine conjugated antibodies $(\mathrm{i}, \mathrm{k})$. Actin was detected with monoclonal actin antibodies and secondary fluorescein conjugated antibodies (j, l). Cells shown in (k, l) were treated with $200 \mathrm{nM}$ jasplakinolide for $60 \mathrm{~min}$ at $37^{\circ} \mathrm{C}$. Picture sizes: $100 \times 100 \mu \mathrm{m}$. For visualization of cells in (a-1) exposure times and photomultiplier settings were chosen to generate no crosstalk between fluorescence channels. Double labeled areas are indicated with $\Rightarrow$. (m)-(n) Sedimentation of ocytlglucopyranoside extracts of P1 endothelial plasma membrane. Membranes obtained by silica perfusion from rat lungs were extracted with octylglucopyranoside in the absence $(\mathrm{m})$ or presence $(\mathrm{n})$ of ATP and centrifuged on 10-35\% sucrose gradients. This experiment was repeated four times with similar results. Fractions were resolved by SDS-PAGE and proteins stained with silver. Molecular weight markers are indicated. Caveolin-1 and actin were assigned by comparing western blots with the silver-stained gel. Sedimentation size markers are indicated for both gels in (n).

contamination and was not analyzed by tandem mass spectroscopy, but later analysis by sucrose velocity sedimentation suggested that it was not so (Figure $2 \mathrm{~m}$, n). On additional similar gels, further varying quantities of the $68 \mathrm{kDa}$ factor in the different gradient fractions were seen (unpublished results). The $45 \mathrm{kDa}$ protein (band 7) corresponded to $\beta / \gamma$ actin and was detected by a precursor ion. Controls by western blotting demonstrated that $5 \%$ of total extracted actin was coprecipitated with caveolin-1 $\alpha$ specifically (data not shown) suggesting that other comigrating proteolytic products hindered in gel digestion and/or sequence determination in this experiment with bulk material. The $32 \mathrm{kDa}$ protein (band 10) was identified as the microsomal form of NADH cytochrome B5 reductase by a total of two proteolytic fragments including a peptide of the microsome-specific $\mathrm{N}$-terminal polypeptide [65, 66]. NADH cytochrome B5 reductase has been identified as a protein with an N-terminal extension in microsomes and the bulk of this enzyme was localized to the endoplasmic reticulum by immunofluorescence microscopy $[65,66]$. Amino acid sequences and sizes for these factors matched their features indicated in protein databases. A database search in the rat genome indicated that the identified peptides of NADH cytochrome B5 reductase could be assigned to a unique gene.

Quantitative immunoblotting experiments (data not shown) demonstrated that $6 \%$ and $8 \%$ of extract ESA/reggie-1/flotillin-2 and reggie-2/flotillin-1, respectively, specifically associated with caveolin-1 $\alpha$ in endothelia, consistent with seminal results obtained on the interaction of reggie/flotillin proteins with caveolin [60]. It is of significance, that the percentage yield of NADH cytochrome B5 reductase in the coimmuno- precipitate was large relative to ESA/reggie-1/flotillin2 and actin, which were discernible as two major bands beneath the $52 \mathrm{kDa}$ marker, whereas the reductase appears as a minor protein in the starting membranes (Figure 4, lane 6). We thus conclude that the reductase is a protein in the membrane fraction that selectively partakes in caveolae functions.

\section{Mechanosignaling and transcription}

Large amounts of the caveolin-1 protein were previously found in caveolae, the Golgi apparatus, lipid bodies and the cytoplasm from several cells, and in secretory granules from pancreas, but not in the ER [67-70]. In Clara cells, caveolin is also present in mitochondria [71]. The scaffolding peptide has amphipathic character (amino acids 60-101), interacts with other proteins and its C-terminal half binds to membranes [72-75]. To further study the exposure of this conformationally flexible region of the protein we raised antibodies reacting with a domain including the signature motif (PROSITE; amino acids 57-77). Cytoplasmic extracts from rat lungs show that caveolin-1 is consistently present in the cytosol fraction (Figure 5a). The antibody was specific and selectively reacted with caveolin- $1 \alpha$ of whole cell extracts of various organs and cells (Figure 5b). There was little reactivity towards caveolin- $1 \beta$ but some phosphorylated caveolin1 was detected in extracts in which caveolin was overall abundant consistent with the absence of potentially phosphorylated amino acids in the 'signature epitope'. Upon incubation of SVEC4-10 cells with the affinity-purified antibodies, we detected caveolin-1 as a brightly labeled protein in the nucleus (Figure 5c, e). This was analyzed by conventional (panels c, d) and confocal microscopy (panels e, f) and demonstrated 


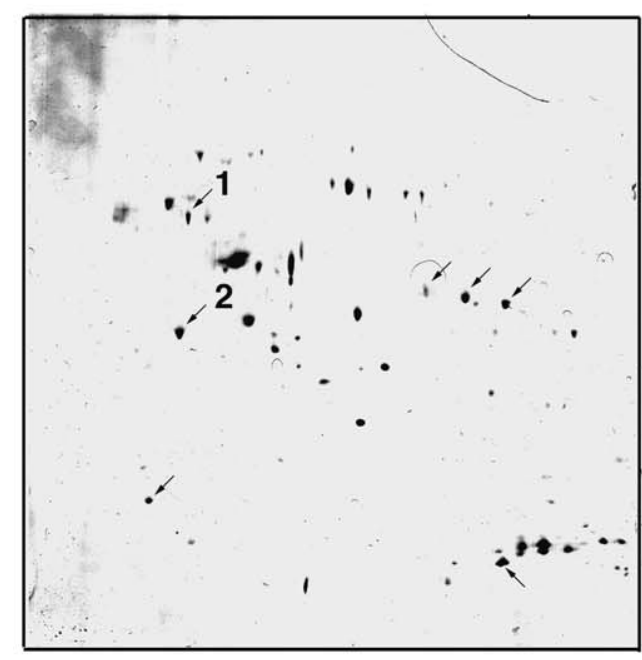

a Starting Material

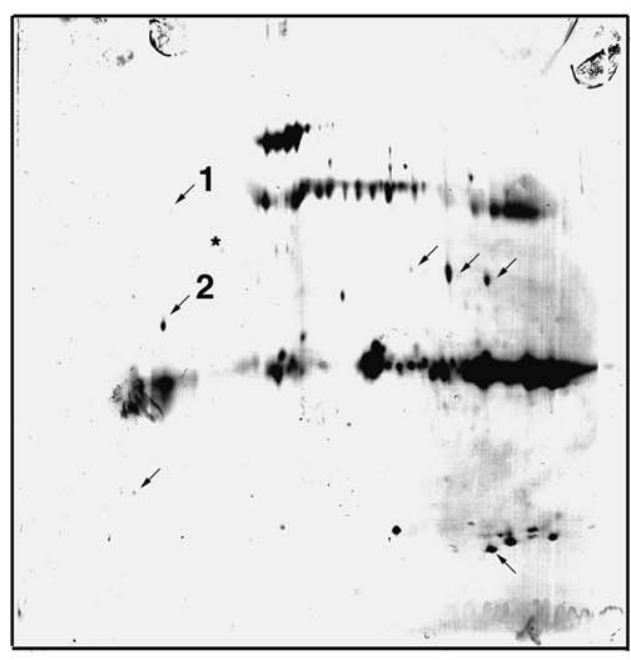

C Specific Binding

1: ATP synthase $\beta$ subunit

TIAMDGTEGLVR 110-121

IPVGPETLGR 134-143

VVDLLAPYAK 189-199

IGLFGGAGVGK 202-212

LVPLKETIK 481-489

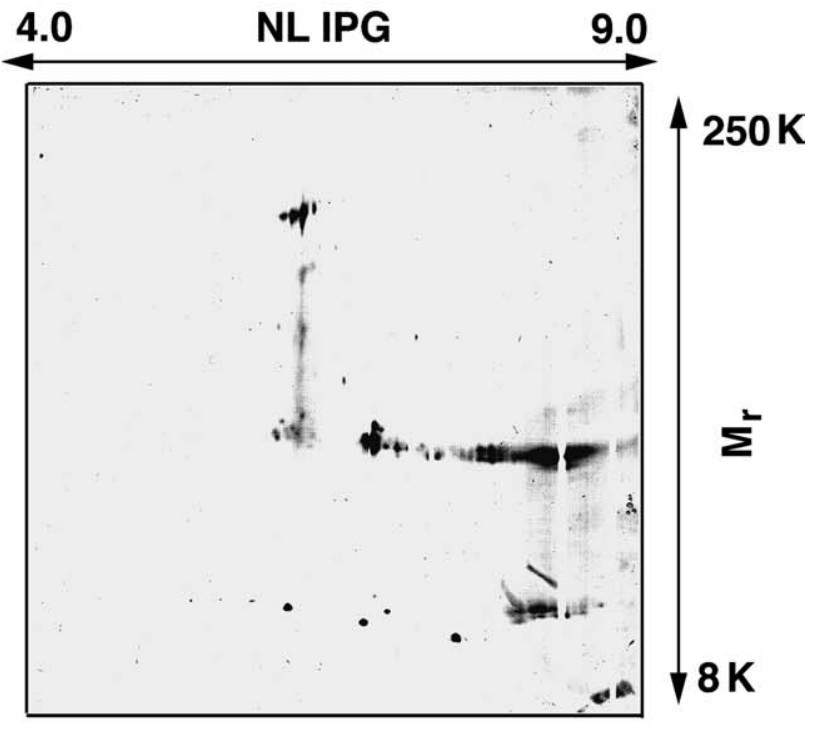

b Unspecific Binding

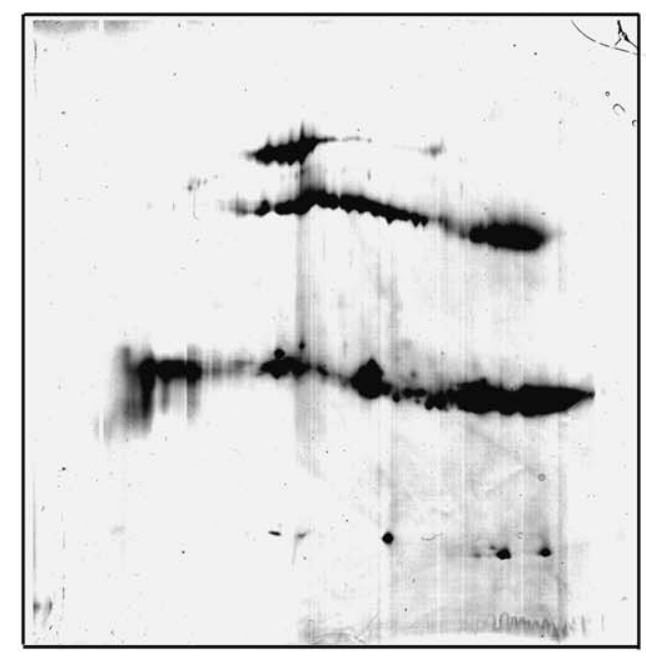

d Antibodies

2: Annexin V

GTVTDFSGFDGR 5-16

QQIAEEFK 49-56

LIVALMKPSR 78-87

VLTEIIASR 107-115

SEIDLFNIR 275-284 


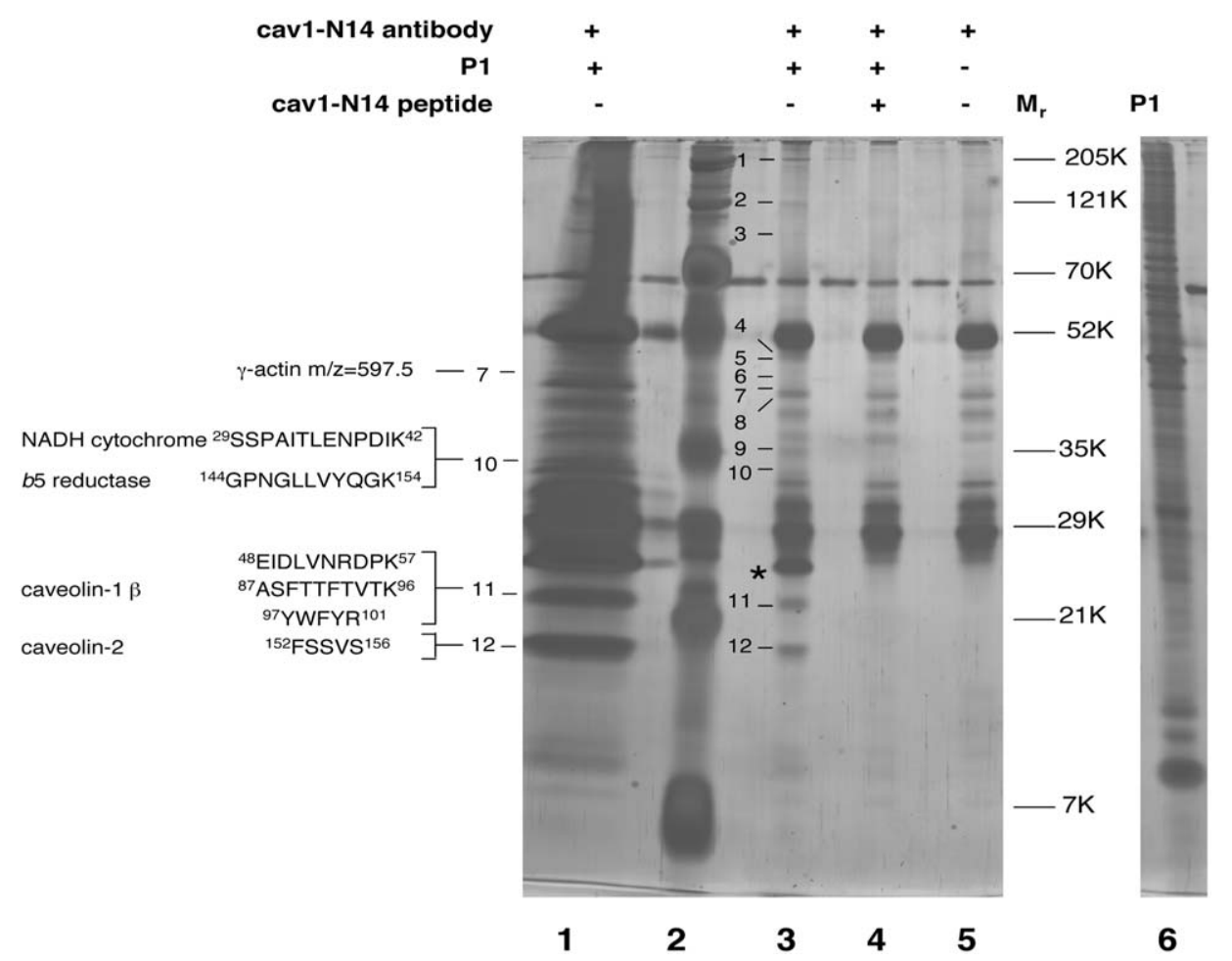

Figure 4. Immunoprecipitation of the caveolin-1 complex. P1 membranes were extracted with octylglucopyranoside and incubated with cav1N14 antibodies (lanes 1,3). Control experiments included the incubation of extract with cav1N14 antibodies in the presence of cav1N14 antigenic peptide (lane 4) and the incubation of cav1N14 antibodies alone (lane 5). Samples were retrieved with protein A sepharose and were resolved by SDS-PAGE, molecular weight standards are in lane 2 and are indicated. $20 \mu \mathrm{g}$ P1 starting material was resolved in lane 6. Preparative amounts of immunoprecipitate (lane 1) allowed to obtain peptide sequence information from bands 7, 10,11 and 12 as indicated, by comparison with the specifically precipitated proteins labeled 1-12 in lane 3. Caveolin-1 $\alpha$ is labeled with an asterik.

that labeling was specific and not present in the presence of antigenic 'signature peptide' (panel d, f) and was also present in multiple sections of the nucleus (data not shown). Despite the abundant presence of caveolin-1 at the plasma membrane in these cells (Figure $2 \mathrm{a}, \mathrm{c})$, caveolae label little with this 'signature' antibody. We infer that caveolin-1 changes conformation and/or that the 'signature epitope' of caveolin-1 is only exposed when the protein is located in the nucleus, and although it is a minor conformer based on the analysis with other antibodies (Figure 2a, c and data not shown) it may carry out a biological function.

\section{Caveolae regulation}

In this work we have begun to analyze the composition of endothelial caveolae, an organelle implicated in blood pressure regulation, calcium influx and ion channel regulation [3, 4, 14, 76-78]. It is essential that internal osmotic pressure gradients in the cell can exist that lead to ion fluxes across the plasma membrane [19], and that plasma membrane proton buffers or dynamics further the local gradient effect $[79,80]$ for our model of caveolae function.

Figure 3. Caveolae immunoisolation and 2D gel analysis. (a)-(d) $300 \mu \mathrm{g}$ of caveolae-enriched membranes (derived from pooled fractions 2-4; Figure 1e) were used for immunoisolation. Membranes were incubated with immunobeads pre-adsorbed without (b, unspecific binding) or with (c, specific binding) affinity-purified cav1N14 antibodies. $25 \mu \mathrm{g}$ of starting-material and antibodies alone are shown in (a) and (d) respectively. They were treated equal to conditions (b) and (c). Samples were resolved on non-linear pH 3.5-10 first dimension IPG strips followed by 9-16\% linear SDS-PAGE gels in the second dimension. Gels were stained with silver ammunium nitrate to detect proteins. Specifically bound proteins are labeled with arrows in $(\mathrm{a}, \mathrm{c})$. The specifically enriched $56 \mathrm{kDa}$ protein, No. 1, and the $36 \mathrm{kDa}$ protein, No. 2 , were identified as mitochondrial ATP synthase $\beta$ chain (1) and annexin V (2) by comparison with a gel from P1 membranes which was used for tandem mass spectroscopy. The major proteins in (d) correspond to BSA, IgG heavy and light chain (in descending order). Actin is marked with an asterik in (c) between '1' and '2'. Caveolin-1 resolves poorly on 2D gels. 
To our surprise, immunoisolated caveolae contain only two major factors, caveolin-1 and ESA/reggie1/flotillin-2, and ATP synthase of mitochondria was also present. ATP synthase is an ADP converting enzyme driven by a chemiosmotic potential [81]. Likewise, the plasma membrane form of ATP syn-

a
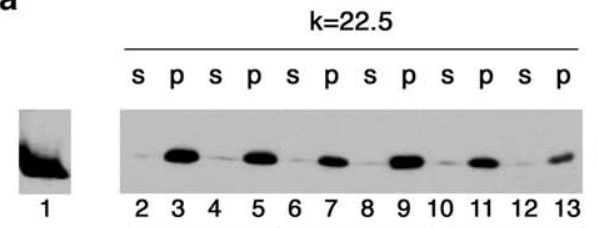

Pellet Supernatant Supernatant Supernatant $k=2025 \quad k=225 \quad k=225$

b

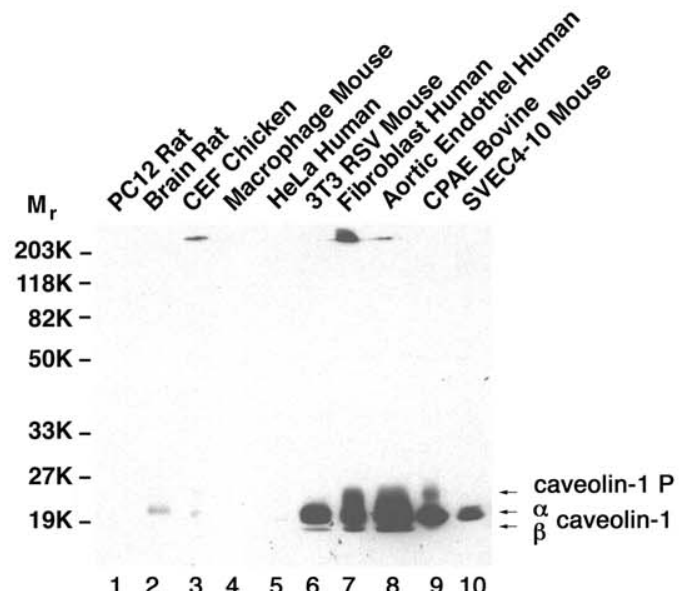

$\begin{array}{llllllllll}1 & 2 & 3 & 4 & 5 & 6 & 7 & 8 & 9 & 10\end{array}$

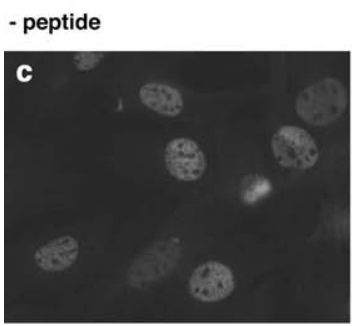

\section{+ peptide}

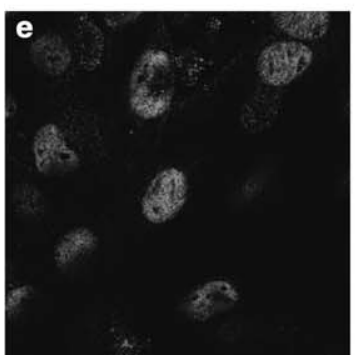

thase [35] may harness the membrane potential and a $\mathrm{pH}$ gradient across the plasma membrane for catalysis. It is notable, that the function in ATP synthesis entails ion channels and/or metabolic differences, and ESA/reggie-1/flotillin-2 homologues have been implicated in ion channel coactivity [52]. According to our model, upon local depolarization of the membrane, triggered by mechanosensitive ion channels, a second messenger, ATP, is generated in the exoplasm to couple endothelial cells with each other and likely to the muscle tonus (see also [82]). ATP synthase may thus integrate effects of pressure stimuli analogous to metabolic changes in mitochondria. The ion fluxes triggered by mechanical pressure, short-term, and any proton fluxes elicited by local conductance, or also by metabolic $\mathrm{pH}$ change, corresponding to a net membrane potential difference of $\sim 200 \mathrm{mV}$ would result in ATP generation. The ionic differences as such can

Figure 5. Caveolin-1 localizes to the nucleus in SVEC4-10 cells. (a) Caveolin-1 is cytosolic. Lung homogenization was carried out with a teflon pestle homogenizer following perfusion of the vasculature. Standard procedures were used to generate a cytosol preparation. The nuclear/mitochondrial pellet of a 10'000 g centrifugation is indicated (lane 1). This pellet includes unlysed cells of the preparation and corresponds to approximately $40 \times$ of the amount of total protein seen in lanes 2-13 (s and p combined, each). Fractionation was carried out by further centrifugations at $100^{\prime} 000 \mathrm{~g}$ in different rotors ( $\mathrm{k}$ factors are indicated). The s (supernatant) fractions lane 2, 4 correspond to cytosol. All sample was recentrifuged at 100 '000 g twice (lanes 6-9 and 10-13) and aliquots were recentrifuged at $100^{\prime} 000 \mathrm{~g}$ to separate a supernatant (s) and pellet (p) fraction. Lanes 10 and 12 correspond to supernatant samples that have been subjected to three $100^{\prime} 000 \mathrm{~g}$ centrifugations in total. Duplicate samples of lanes 4,5, 8,9, 12,13 were subjected to quick freezing in liquid nitrogen before further processing. Samples were resolved by SDS-PAGE and caveolin-1 was detected by western blotting with caveolin-1 polyclonal antibodies and enhanced chemiluminescence. Material lighter than $1.04 \mathrm{~g} / \mathrm{cm}^{3}$ remains in the supernatant fraction. (b) Characterization of the caveolin-1 signature antibody. Equal amounts of cell or organ extract were resolved on 12\% SDS-PAGE and incubated with affinity-purified caveolin-1 signature antibodies. Caveolin- $1 \alpha$ resolves as the major protein band with little caveolin-1 $\beta$ detected beneath. The phosphorylated form of caveolin-1 is indicated (by comparison). Nitrocellulose blots were developed by enhanced chemiluminescence. Molecular weight standards are indicated. (c)-(f) Caveolin-1 localization in SVEC4-10 cells as detected with caveolin-1 'signature' antibodies. Cells were grown on collagen I coated coverslips. Caveolin-1 was visualized in the nucleus with affinity-purified 'signature' antibodies in the absence (c, e) or presence $(d, f)$ of antigen peptide and detected with secondary rhodamine conjugated anti-rabbit antibodies. Identical results were obtained with affinity-purified antibodies of bleads from two different rabbits. Cells were viewed and photographed/scanned with a Zeiss Axiovert immunofluorescence microscope (c, d) or a Leica confocal microscope (e, f). 
also be considered an important determinant of local protein function.

A multitude of factors have previously been identified in lipid raft preparations, but since they are not specific with respect to temperature of isolation [83], nor free of membranes coated with clathrin [84], we will not discuss them in detail. The subcellular fractionation of lipid raft subdomains has been further advanced by use of different detergents, but in each case, the relationship to each other and percentage total in caveolae has not been determined (see e.g. [85]), and thus these data do not contribute to further understanding with respect to caveolae without subcellular localization [86].

On the cellular level, endothelia release hyperpolarizing factors which act as dilators for the muscle cell layer. Calcium-dependent potassium channels in endothelial smooth muscle cells have been implicated in setting vascular tonus [87] and, strikingly, also potassium release by endothelial potassium channels affects the potassium-sensitive potassium channels to trigger hyperpolarization in muscle [88]. Similar to synaptic signaling, we suggest that, here, in contrast, the local generation and release of ATP from endothelia regulates muscle tonus by binding to muscle $\mathrm{P} 2 \mathrm{X}$ receptors [89]. $\mathrm{P} 2 \mathrm{X}$ receptors are ionotropic and may amplify the ATP signal if present in signal conducting endothelial cells [90, 91]. In contrast, P2Y receptors are heptahelical and of metabotropic type, couple extracellular ATP and ADP and other nucleotides to intracellular signaling by trimeric $\mathrm{G}$ proteins, phospholipase $\mathrm{C} \beta$ and calcium signaling, and regulate NO production [92]. This idea is consistent with paracrine signaling in tubuloglomerular regulation of vascular tone [92-94]. In this vascular bed, adenosine receptors on muscle play a pivotal role in constriction [94]. The balance of nucleotide supply, ATP generation by ATP synthase and nucleotide diphosphokinase, as well as nucleotide hydrolysis, determine the concentration of the nucleotide species [92] within caveolae, inline with a previously proposed function of caveolae of signaling integration [47, 67]. ATP synthase at the plasma membrane also hydrolyzes extracellular ATP, generates a proton gradient with an endocytic function in hepatic cells and is awaiting further mechanistic analyses [41]. The effect of acidosis on vasoconstriction and mechanosignaling remains to be analyzed on the molecular level, but intricately depends on the ratio of intracellular and extracellular $\mathrm{pH}$ [95]. A function of ATP in adhesion and the interaction of caveolin-1 with integrins may furthermore point towards its role in mechanotransduction [27, 96, 97]. A recent study has described the interaction of adhering cells with their environment, and uncovered the counterintuitive behaviour that cells escape from strain in area but grow towards it [98], suggesting that a multitude of signaling pathways must be involved.

The presence of NADH cytochrome B5 reductase in caveolae has not been observed and we report specific interaction of the reductase with caveolin-1 in detergent extracts of rat lung endothelial plasma membrane as well as faint punctate plasma membrane localization (data not shown). Faint plasma membrane localization in addition to the ER location of NADH cytochrome B5 reductase can also be observed in the original work [66], but plasma membrane localization of enzymes and markers is often initially discounted as a minor fraction if also localized to tubular compartments, since for geometrical reasons and lack of resolution the signal of the entire tubular structure is increased. Although NADH cytochrome B5 reductase is a minor component visible on silver-stained gels in the coimmunoprecipitation, it tightly interacts with caveolin-1 and its \% total yield in the isolate relative to starting membranes is high compared to coimmunoprecipitating actin and ESA/reggie-1/flotilllin-2. Desaturases are coupled to the reductase by the electron shuttling enzyme cytochrome B5. Cytochrome B5 is loosely associated [99], and is generally assumed to transfer electrons derived from $\mathrm{NADH}$ to oxygen, to convert $\mathrm{C}-\mathrm{C}$ bonds to $\mathrm{C}=\mathrm{C}$ double bonds in lipid desaturation, but may also have other acceptors. The reaction is implicated in acyl-CoA desaturation of various acyl chains, cholesterol and plasmalogen biosynthesis [100-103].

The fluidity of the membrane bilayer is affected in mechanosignaling [32], and by lipid desaturation, as known for many cells in cold adaptation. If lipid gradients, seemingly implicated in lipid transfer between two locations, persist long enough, a microenvironment may be generated to regulate mechanotransduction factors by the enzymatic action of the desaturase components and by lateral pressure changes, as shown for prototypical membrane channels in model calculations [104]. Further supporting is the lipid rigidifying function of annexin $\mathrm{V}$ which may contribute to the regulation of this process [105]. A general role of caveolin in lipid metabolism, as suggested by analysis of caveolin-1 knockout mice [106], recent immunoisolation from adipocytes [15], and activated recruitment to lipid bodies [70] is likely, but in view of a large fraction of ER and mitochondrial reductase and desat- 
urase enzymes, this quartenary chain may carry out a specific role in caveolae.

The presence of caveolin-1 in the nucleus of endothelial cells indicates that similar to lipoprotein assembly, which involves apolipoprotein extrusion from the membrane, caveolin-1 dislocates from the plasma membrane and likely signals to the nucleus. We expect that a single explanation for nuclear occurrence of the protein is not warranted [107]. The details of caveolin signaling and release, conformational switching and nuclear import will be subject to future studies.

\section{Materials and methods}

\section{Materials}

Sucrose (SigmaUltra), HEPES, EDTA, bovine serum albumin (BSA), ketamine, xylazine, sodium nitroprusside, heparin, morpholino ethane sulfonic acid, $\mathrm{NaCl}$, Nonidet P-40, deoxycholate, sodium dodecylsulfate, octyl- $\beta$-D-glucopyranoside, 1,10phenanthroline, PMSF, pepstatin and molecular weight sedimentation calibration kit MW-GF 1000 were purchased from Sigma. The gradient fractionator was from Labconco. $\mathrm{KCl}$, Tris and $\beta$ mercaptoethanol, DMSO, salicylate, glycerol and EGTA were bought from Merck, Triton X-100, leupeptin and E64 protease inhibitor from Boehringer Mannheim and Tween-20, PVDF membranes, the horseradishperoxidase-coupled goat anti-mouse and anti-rabbit antibodies and the Bradford assay from BioRad. Colloidal silica Nalco 1060 (average diameter $50 \mathrm{~nm}$ ) was from Nalco Chemicals, aluminum chlorohydroxide from Pfaltz \& Bauer and poly(acrylic acid) (average $\mathrm{M}_{\mathrm{w}} \sim 240$ '000) from Aldrich. ATP and the enhanced chemiluminescence (ECL) reagents were from Boehringer Mannheim. ECL reagents were also bought from NEN. Ponceau S was from Serva. Catheters $16 \mathrm{G} / 2 \mathrm{IN}$ were from Beckton Dickinson and surgical suture $45 \mathrm{~cm} / 2-0$ silk/CE-6/24 mm from American Cyanamid. Nycodenz was from Gibco BRL. The homogenizer (S-type) was from Braun. Protran BA85 nitrocellulose was purchased from Schleicher \& Schuell. The caveolin-1 monoclonal antibodies C43420, C13620 and polyclonal antibody C13630, the ESA E35820 and flotillin F65020 monoclonal antibodies and control lysates of different cells and brain were from Transduction Laboratories. The caveolin-1 monoclonal antibody $\mathrm{Cl}$. Z034 was from Zymed and Cl. 2283 from ICN. The $\beta$-actin AC15 monoclonal antibody was from Sigma. The Cy3 and fluorescein conjugated goat anti-mouse and goat anti-rabbit antibodies were from Jackson Immuno Research Laboratories and Cappel, respectively. The rhodamine and fluorescein conjugated goat anti-mouse and -rabbit antibodies were from ICN. Jasplakinolide was from Molecular Probes. ProteinA-sepharose was from Pharmacia. Express $\mathrm{S}^{35}$-Met/Cys protein label was from ICN. Dynabeads M280 were bought from Dynal. Sepharose Cl-4B beads were from Pharmacia. The rat caveolin-1 $\alpha \mathrm{N}$-terminal peptide (cav1N14; amino acid residues 1-14-Cys) was synthesized by the Microchemistry Core Facility of the Rockefeller Research Laboratories, Sloan Kettering-Institute. The peptide 57-77-Cys of rat caveolin- $1 \alpha$ (signature peptide) was from Neosystems. Reagents for 2D gel analysis were from the following sources: 2,7 naphtalene disulfonic acid was from Acros, acetic acid, ammonia, citric acid, dithiothreitol, ethanol, formaldehyde, glycerol, hydrochloric acid, methanol, paraffine oil, sodium acetate, Tris base and urea from Merck, acrylogelpiperazine diacrylyl 2.6 solution and Resolytes $\mathrm{pH} 4-8$ from BDH, agarose from Eurogentec, Coomassie brilliant blue R-250, ammonium persulfate and sodium dodecylsulfate from Bio-Rad, bromophenol blue, glutaraldehyde, glycine, butan-2-ol, silver nitrate and sodium thiosulfate from Fluka, cholamidopropanesulfate, iodoacetamide and thiourea from Sigma, IPG NL $\mathrm{pH}$ 3.5-10 strips from Pharmacia-Hoeffer and TEMED from Serva. CPA endothelial cells (batch F13887) and SVEC4-10 cells (batch 204826) were from the American Type Culture Collection (ATCC). Media for tissue culture (as indicated by ATCC), fetal bovine serum, Trypsin-EDTA, penicillin/streptomycin and Glutamax were from Gibco/BRL. Trypsin was from Promega. Collagen (rat tail type I) was purchased from Collaborative Biomedical Products.

\section{Methods}

\section{Database search}

Database searches were carried out with the Rat BLAT Search, Jan. 03 assembly (http://genome.ucsc.edu).

\section{Caveolin-1 antibody production}

The rat cav1N14 and rat caveolin-1 $\alpha$ 57-77 'signature' peptides were coupled to keyhole limpet hemocyanin via $\mathrm{C}$-terminal cysteines, antibodies were raised in rabbits (three and two, respectively) with 
Freund's adjuvant. For affinity-purification peptidecoupled Sepharose Cl-4B beads were used according to standard procedures. The antisera (cav1N14) were screened by immunoprecipitation of caveolin- 1 from P1 membrane 1\% TritonX-100, 0.05 Tween-20 (in PBS) extracts warmed to $37^{\circ} \mathrm{C}$ for 5 min during extraction followed by incubation at $4{ }^{\circ} \mathrm{C}$, centrifugation and addition to the immunobeads. These were incubated and processed as described below. Efficiency of caveolin-1 immunoprecipitation was quantified by western blotting with caveolin-1 polyclonal antibody (C 13630). Antibody incubations were in PBS, 5\% fat-free milk and $0.2 \%$ Tween-20.

\section{Membrane isolation from rat lungs}

Coating of colloidal silica and rat lung perfusion was carried out according to Jacobson et al., [108]; animals were anaesthetized before the experiment. Protease inhibitor mix consisted of $1 \mathrm{mM}$ 1,10-phenanthroline, $1 \mathrm{mM}$ PMSF and a cocktail of $2 \mu \mathrm{g} / \mathrm{ml} \mathrm{E} 64$, $10 \mu \mathrm{g} / \mathrm{ml}$ leupeptin, $10 \mu \mathrm{g} / \mathrm{ml}$ pepstatin $(1000 \times$ stock in DMSO) (PIC) and was added to the homogenates. A P1 and P2 silica pellicle fraction was obtained by one or two centrifugations, respectively, through a nycodenz cushion as described.

\section{Electron microscopy}

The P1 fraction was fixed in $2.5 \%$ glutaraldehyde in PIPES buffer $\left(20 \mathrm{mM}\right.$ ), postfixed in $2 \% \mathrm{OsO}_{4}$ (in $\mathrm{H}_{2} \mathrm{O}$ ) for one hour and dehydrated in a graded series of EtOH. Samples were embedded in Polybed 812 (Polysciences) and sectioned $(60 \mathrm{~nm}$ ) with a Reichert Ultracut $\mathrm{S}$ ultramicrotom. Samples were poststained with 5\% uranylacetate, $0.4 \%$ lead citrate in $\mathrm{MeOH}$ and viewed and photographed with JEOL 1200 Ex electron microscope.

\section{Immunoisolation of caveolae from rat lungs}

Immunoisolation was carried out according to Stan et al. with minor modifications [9]. The P1 fraction $(12 \mathrm{mg}$ ) was sonicated for $4 \times 20 \mathrm{sec}$ in a buffer containing $2 \mathrm{M} \mathrm{KCl}$ and $31 \mathrm{mM}$ HEPES pH 7.4, PIC and $1.25 \mathrm{mM}$ PMSF/phenanthroline. Sonication was intermittent with cooling in-between on ice. Samples were adjusted to $1.7 \mathrm{M}$ sucrose, $10 \mathrm{mM}$ HEPES $\mathrm{pH}$ 7.4, $2 \mathrm{mM}$ EDTA, $630 \mathrm{mM} \mathrm{KCl}$ final concentration and loaded into a TST41.14 centrifuge tube, overlaid with $4 \mathrm{ml} 1.09 \mathrm{M}$ sucrose in $500 \mathrm{mM} \mathrm{KCl}, 10 \mathrm{mM}$ HEPES $\mathrm{pH} 7.4$ and a $1 \mathrm{ml}$ cushion of $0.25 \mathrm{M}$ sucrose in
$500 \mathrm{mM} \mathrm{KCl}, 10 \mathrm{mM}$ HEPES $\mathrm{pH}$ 7.4. The samples were centrifuged for $13 \mathrm{~h}, 40$ '000 rpm at $4{ }^{\circ} \mathrm{C}$ in the ultracentrifuge. Fractions were collected from the gradient with a gradient maker and a small quantity was resolved by SDS-PAGE. The remainder $(340 \mu \mathrm{g})$ was used for immunoisolation. Membranes were diluted fourfold with $0.1 \%$ BSA, 2 mM EDTA in PBS (IB) and PIC was added before isolation. All tubes for immunoisolation ( $2 \mathrm{ml}$, Eppendorf) were preincubated with IB for $30 \mathrm{~min}$ before addition of reagents. For the analytical experiment (Figure 1f) $50 \mu \mathrm{l}$ Dynabeads M280 coated with sheep anti rabbit IgG were pre-incubated with IB and then with or without $12 \mu \mathrm{g}$ caveolin-1 N1-14 (cav1N14) affinity-purified antibodies overnight at $4{ }^{\circ} \mathrm{C}$, excess antibodies were removed by an IB wash. Sample membranes $(2 \times 23 \mu \mathrm{g})$ were added to the tubes for overnight incubation with gentle shaking at $4{ }^{\circ} \mathrm{C}$. Samples were washed with four loads of ice cold IB by retrieval with a magnet, once with PBS and loaded onto the gel. For large scale isolation the amount of beads and antibodies were doubled for each reaction tube and 10 tubes in total were used, 5 for the control reaction in the absence of antibodies and 5 for the specific retrieval with $150 \mu \mathrm{g}$ protein each, BSA was increased to $2 \mathrm{mg} / \mathrm{ml}$ for the overnight incubation in the membrane addition step. Samples and controls were treated identically, this included the incubation of Dynabeads without antibodies or incubation of cav1N14-coated Dynabeads without membranes except that the 'antibody only' incubation was carried out in 2 tubes overnight following the precoating with cav1N14 antibody. The precoating was carried out with the total amount of Dynabeads in one tube in all experiments to avoid slight experimental variations and pipetting errors. The residual of the pooled fractions $2-4(2 \times 20 \mu \mathrm{g})$ of the original gradient was diluted three-fold with PBS and spun at $100^{\prime} 000 \mathrm{rpm}, 4{ }^{\circ} \mathrm{C}$ in a TLA100.2 rotor (Beckman) to pellet membranes and for gel loading (for silverstain and western blotting). Protein amounts were determined with the Bradford assay. Samples were solubilized in $350 \mu \mathrm{l} 2 \mathrm{D}$ sample loading buffer including a trace of bromophenol blue for $25 \mathrm{~min}$ at $37^{\circ} \mathrm{C}$, $1^{\prime} 500 \mathrm{rpm}$ in a Thermomixer (Eppendorf). Samples were spun for $10 \mathrm{~min}$ at room temperature in the Eppendorf centrifuge at $14^{\prime} 000 \mathrm{rpm}$ and supernatants were used for the 2D gel analysis. The polyacrylamide gels were stained with silver to visualize the resolved proteins [109]. This silver stain was used in all analytical methods. For the experiment shown in Figure 1g, $\mathrm{h}$ we employed Eupergit $\mathrm{C} 1 \mathrm{Z}$ beads for the immun- 
oisolation. The immunoisolation buffer was the same (IB) except that BSA was adjusted to $2 \mathrm{mg} / \mathrm{ml}$. C1Z beads (a kind gift of Eric Dumermuth, Basel and Annette Hille-Rehfeld, Göttingen) were coupled to sheep anti rabbit Fc fragments as described [110]. $6 \mu \mathrm{g}$ of affinity-purified cav1N14 antibodies were added to the caveolae-enriched membrane fraction (diluted 1:3 in IB) and incubated overnight at $4{ }^{\circ} \mathrm{C}$ with gentle shaking (for one tube and reaction). Membranes for this immunoisolation were obtained from a P1 membrane fraction as described above except that intermittent sonication was carried out $2 \times 30 \mathrm{sec}$ on ice and the use of a SW60 rotor for membrane fractionation in the sucrose density gradient. Here cushions were identical, samples were centrifuged for $210 \mathrm{~min}$, 50 '000 rpm at $4{ }^{\circ} \mathrm{C}$ and the $0.25 \mathrm{M} / 1.09 \mathrm{M}$ sucrose interface was collected by fractionation with a gradient maker. Amounts were too small to determine and are visible on the Ponceau $\mathrm{S}$ stained nitrocellulose blot. $60 \mu \mathrm{l}$ of a 1:1 suspension of coupled Eupergit $\mathrm{C} 1 \mathrm{Z}$ beads were preincubated with IB for 1 hour at $4{ }^{\circ} \mathrm{C}$ and then added to the membranes. The incubation was continued for 3 hours and followed by four washes in IB and one wash in PBS. Centrifugation of Eupergit beads was carried out for $5 \mathrm{~min}$ in an Eppendorf centrifuge at 2'500 rpm at $4{ }^{\circ} \mathrm{C}$ for pelleting during washes. For western blotting of these samples the reggie- 1 monoclonal antibody was used at a concentration of $0.5 \mu \mathrm{g} / \mathrm{ml}$. Caveolin- 1 was detected with the mixture of C43420, C13620, Cl. Z034, Cl. 2283 caveolin- 1 monoclonal antibodies $(0.05 \mu \mathrm{g} / \mathrm{ml}$, $0.25 \mu \mathrm{g} / \mathrm{ml}, 0.05 \mu \mathrm{g} / \mathrm{ml}, 0.2 \mu \mathrm{g} / \mathrm{ml}$ concentration) by western overlay.

\section{D IPG-SDS-PAGE and western blotting}

IPG strips $\mathrm{pH} 3.5-10(18 \mathrm{~cm})$ were loaded for 12 hours during rehydration. Loading buffer was as described [111]. The machine (Pharmacia) was programmed in voltage steps of $500 \mathrm{~V} 1 \mathrm{~h}, 1000 \mathrm{~V} 1 \mathrm{~h}$, $2000 \mathrm{~V} 30 \mathrm{~min}, 4000 \mathrm{~V} 30 \mathrm{~min}, 8000 \mathrm{~V}$ to $90 \mathrm{kVh}$ total and $500 \mathrm{~V}$ holding voltage. The voltage ramped to 5'500 V maximum. The procedure included slight modifications from the method previously described. Strips were equilibrated with $3 \mathrm{ml}$ of $50 \mathrm{mM}$ Tris $\mathrm{pH}$ 6.8, $6 \mathrm{M}$ urea, 30\% v/v glycerol, 2\% SDS, $2 \%$ dithiothreitol followed by incubation in $3 \mathrm{ml} 50 \mathrm{mM}$ Tris $\mathrm{pH}$ 6.8, $6 \mathrm{M}$ urea, $30 \%$ glycerol (v/v), $2.5 \%$ iodoacetamide and a trace of bromophenol blue for 5 min. Second dimensions (BioRad) were run as 9-16\% gradient gels with acrylamide/piperazine diac- rylyl as crosslinker $(9-16 \% \mathrm{~T}, 2.6 \% \mathrm{C})$. The gels contained $1.25 \mathrm{mg} / \mathrm{ml}$ thiosulfate. Second dimensions (without a stacking gel) were overlaid with a solution of $0.5 \% \mathrm{w} / \mathrm{v}$ agarose in $25 \mathrm{mM}$ Tris $\mathrm{pH} 8.3$, $190 \mathrm{mM}$ glycine, $0.05 \% \mathrm{SDS}$ and $0.8 \mathrm{mM}$ EDTA. They were run at constant voltage $50 \mathrm{~mA} / \mathrm{gel}, 8^{\circ} \mathrm{C}$ for approximately 5.5 hours until the dye front reached the bottom of the plate. For control blots on PVDF membranes a Towbin-buffer of $25 \mathrm{mM}$ Tris, $190 \mathrm{mM}$ glycine with $0.05 \%$ SDS, without methanol, was used. Preparative gels were run the same and stained with Coomassie brilliant blue R-250. Silver staining of analytical samples on 2D gels was done as published with an ammoniacanial silver nitrate solution and the following modifications of adding $0.05 \%$ 2,7-naphtalenedisulfonic acid to the washes after sensitization in $2.5 \%$ glutaraldehyde with $0.5 \mathrm{M}$ sodium acetate in water (pers. comm. H. Leffers). Gels were incubated with a solution of $25 \%$ ethanol, $2 \%$ PEG-4000 and dried on a standard gel dryer or left in the same solution. Some gels stored in sealed plastic bags inadvertently dried as well. Western blotting was carried out with caveolin- 1 antibodies with a mixture of $\mathrm{C} 43420$, C13620, Cl. Z034, Cl. 2283 caveolin-1 monoclonal antibodies (concentrations $0.05 \mu \mathrm{g} / \mathrm{ml}, 0.25 \mu \mathrm{g} / \mathrm{ml}$, $0.05 \mu \mathrm{g} / \mathrm{ml}, 0.2 \mu \mathrm{g} / \mathrm{ml}$ ) or caveolin-1 polyclonal antibody (at $50 \mathrm{ng} / \mathrm{ml}$ ). Gels were compared to standard gels on the Expasy-Server (http://www.expasy.ch).

\section{Velocity sedimentation}

$200 \mu \mathrm{g}$ of P1 membranes were extracted in $300 \mu \mathrm{l}$ final volume of $40 \mathrm{mM}$ octyl- $\beta$-D-glucopyranoside in TNE buffer (25 mM Tris- $\mathrm{HCl} \mathrm{pH} 7.5,100 \mathrm{mM} \mathrm{NaCl}$, $2 \mathrm{mM}$ EGTA, $1 \mathrm{mM} \mathrm{MgCl} 2,2 \% \beta$-mercaptoethanol, PIC) for $5 \mathrm{~min}$ at $37{ }^{\circ} \mathrm{C}$ in an Eppendorf 5436 shaker (1'000 rpm) and then for $30 \mathrm{~min}$ at $4{ }^{\circ} \mathrm{C}$ on a rotary shaker. $2 \mathrm{mM}$ ATP was added where indicated to the extraction mix and sucrose gradient solutions. The silica particles were pelleted by centrifugation $10 \mathrm{sec}, 4{ }^{\circ} \mathrm{C}, 14^{\prime} 000 \mathrm{rpm}$ in an Eppendorf centrifuge. Supernatants were added on top of a $10-35 \%(\mathrm{wt} / \mathrm{vol})$ sucrose gradient. The linear gradient was poured with the density gradient maker/fractionator with TNE solution containing $40 \mathrm{mM}$ octyl- $\beta$-D-glucopyranoside, no PIC. Consistency was controlled by refractometry. Centrifugation was for $22 \mathrm{~h}, 30^{\prime} 000 \mathrm{rpm}, \mathrm{SW} 60 \mathrm{Ti}$ rotor and $12^{\circ} \mathrm{C}$. $400 \mu \mathrm{l}$ fractions were collected from the top of the gradient with the density gradient fractionator. Fractions were acetone precipitated. Samples were separ- 
ated by $12 \%$ SDS-PAGE after boiling in SDS-PAGE sample buffer. Sedimentation coefficients of protein complexes were estimated by comparison with standard proteins centrifuged in the same experiment: carbonic anhydrase (29 kDa), BSA (66 kDa, 4.3 S), alcohol dehydrogenase (150 kDa, 7.4 S), $\beta$-amylase (200 kDa, $9 \mathrm{~S})$, apoferritin (443 kDa), and thyroglobulin (669 kDa, $19 \mathrm{~S})$. S values were taken from published data.

\section{Caveolin immunoprecipitation}

$15 \mathrm{mg}$ of the silica pellicle $\mathrm{P} 1$ endothelial luminal plasma membranes were extracted for $90 \mathrm{~min}$ in IP buffer. IP buffer was $40 \mathrm{mM}$ octyl- $\beta$-Dglucopyranoside, $1 \mathrm{mM}$ EDTA, $0.5 \mathrm{mM}$ PMSF, $0.5 \mathrm{mM}$ 1,10-phenanthroline, $1 \mathrm{mM}$ DTT in PBS containing PIC. The material was centrifuged for $10 \mathrm{~min}$ at $14^{\prime} 000 \mathrm{rpm}$ in the Eppendorf centrifuge; the supernatant was brought to $1 \mathrm{mg} / \mathrm{ml} \mathrm{BSA}$ final concentration. The extract was precleared for $60 \mathrm{~min}$ with $500 \mu \mathrm{l}$ protein A-Sepharose (1:1 in IP buffer, preblocked with $5 \mathrm{mg} / \mathrm{ml} \mathrm{BSA}$ for $1 \mathrm{~h}$ and washed $3 \times$ before use). These beads were discarded. For lane 1 (Figure 4) caveolin-1 was immunoprecipitated from $12 \mathrm{mg}$ corresponding extract with cav1N14 affinitypurified antibodies, for the analytical lanes 3-5 $1.5 \mathrm{mg}$ each was used with equal amounts of antibodies with or without excess ( $8^{\prime} 000$-fold, molar) of cav1N14 peptide (preincubated with the antibody). As a further control excess of antibody (150 $\mu \mathrm{g})$ was loaded onto the same gel (not shown) to allow comparison with possibly abundant affinity-purified antibody contaminants. Incubation of extracts was overnight, $4{ }^{\circ} \mathrm{C}$. Antigen-antibody complexes were collected by protein A-Sepharose retrieval (preblocked with IP buffer containing $5 \mathrm{mg} / \mathrm{ml} \mathrm{BSA} 1 \mathrm{~h}$ at $4{ }^{\circ} \mathrm{C}$ ). Incubation was for $1 \mathrm{~h}$ at $4{ }^{\circ} \mathrm{C}$, followed by 2 washes with IP buffer (with $1 \mathrm{mg} / \mathrm{ml} \mathrm{BSA}$ ) and 2 washes with PBS. Samples were separated by $12 \%$ SDS-PAGE after boiling in Laemmli SDS-PAGE sample buffer. Gels were stained with a modified, aqueous silver staining protocol.

\section{Microsequencing}

Microsequencing was carried out by electron spray ionization mass spectral analysis (ESI-MS). 2D gels were run with $1.4 \mathrm{mg}$ of $\mathrm{P} 1$ and $\mathrm{P} 2$ membranes from rat lung luminal endothelial plasma membrane and gel spots were combined after Coomassie blue staining and computational comparison with the immunoisolate and starting membranes (Figure 3). The electrophoretic programming and conditions of the 2D gel run were identical. From one dimensional gels, samples were excised following staining of the gels with silver as described previously. Gel pieces were excised and washed five times with $30 \mu \mathrm{l}$ each of $40 \%$ n-propanol, followed by five washes with $30 \mu \mathrm{l}$ each of $200 \mathrm{mM} \mathrm{NH} 4 \mathrm{HCO}_{3}$ containing $50 \%$ acetonitrile and dried in a speed vac concentrator. For digestion, $0.5 \mu \mathrm{g}$ trypsin in $10 \mu \mathrm{l} 100 \mathrm{mM} \mathrm{NH} \mathrm{NCO}_{3}$ was added to allow reswelling of the gel pieces. Enough $100 \mathrm{mM} \mathrm{NH}_{4} \mathrm{HCO}_{3}$ was added to completely immerse the gel pieces in the liquid. Digestion was at $37^{\circ} \mathrm{C}$ for two hours. The supernatant was collected and the gel pieces were extracted twice with $15 \mu \mathrm{l}$ each of $0.1 \%$ formic acid followed by extraction twice by $15 \mu \mathrm{l}$ acetonitrile. All supernatants were pooled and dried in a speed vac rotator. For mass spectral analysis, the peptides were redissolved in $10 \mu \mathrm{l} 0.1 \%$ trifluoroacetic acid and $5 \mu \mathrm{l}$ were injected onto a capillary column (100 $\mu \mathrm{m}$ i.d.) packed with POROS R2 material. The peptides were eluted with a linear gradient of $0.02 \%$ acetic acid to methanol containing $0.02 \%$ acetic acid in $15 \mathrm{~min}$ at a flow rate of approximately $200 \mathrm{nl} / \mathrm{min}$. Eluting peptides were introduced into the mass spectrometer via a microelectrospray ion source. Mass spectral data were acquired on a TSQ7000 triple quadrupole instrument (Finnigan, San José, CA) with data controlled switching between precursor ions and daughter ions during a single chromatographic run. For precursor ion scanning, the resolution of the instrument was set to 1 Dalton. For operation in the MS/MS mode, the resolution of Q1 was set to transmit a window of 4 Dalton and the resolution of Q3 was adjusted to 1.5 Dalton. Daughter ion scanning was performed between 50 to 2'000 Dalton in $3.5 \mathrm{~s}$. Argon was used as the collision gas at a pressure of 3.0 mTorr. The collision energy was kept constant at $-32 \mathrm{eV}$ during individual experiments. The daughter ion spectra acquired were used to identify the proteins with the SEQUEST program [112] and Mascot search software. For actin and reggie/flotillin quantitation in the coprecipitate $500 \mu \mathrm{g}$ corresponding P1 membrane extract was used and solublized in $500 \mu 1$ of the same solutions as described above (caveolin immunoprecipitation). Treatment was identical. Specifically coprecipitating proteins were analyzed by peptide competition, $100 \mu \mathrm{g}$ corresponding P1 membrane extract was used for a concentration series for western blotting in parallel to allow comparison and to determine the linearity of the antibody response. Actin was detected with the AC15 monoclonal anti- 
body, ESA/reggie-1/flotillin-2 and reggie-2/flotillin-1 with ESA and flotillin antibodies, respectively, followed by secondary HRP-coupled mouse antibodies. ECL exposures were quantified by densitometry.

\section{Cytosol preparation}

Rat lung cytosol was prepared by standard perfusion [108] with Dulbecco's MEM with sodium nitroprusside for $2 \mathrm{~min}$ at r.t. followed by $4 \mathrm{~min}$ at $8{ }^{\circ} \mathrm{C}$ and 6 min with cytosol buffer $(25 \mathrm{mM}$ Tris $\mathrm{pH}$ 7.4, $500 \mathrm{mM} \mathrm{KCl}, 1 \mathrm{mM}$ DTT, $250 \mathrm{mM}$ sucrose, $2 \mathrm{mM}$ $\mathrm{MgCl}_{2}, 5 \mathrm{mM}$ EGTA and PMSF, 1,10-phenathroline, PIC. Tissue was processed as described for $\mathrm{P} 1$ pellicle preparation, that is homogenization with a Dounce (S-type, 20 strokes) and filtration. Filtrate was controlled in the microscope for cell lysis and appearance of nuclei. The sample was spun sequentially for $1 \mathrm{~h}$, 10'000 rpm, TST60, for $1 \mathrm{~h} \mathrm{30'000} \mathrm{rpm,} \mathrm{TST60,} \mathrm{for}$ $1 \mathrm{~h}, 30$ '000 rpm, TST60 all at $4{ }^{\circ} \mathrm{C}$. Supernatants of each run were recentrifuged for $1 \mathrm{~h}, 50$ ' $000 \mathrm{rpm}$, TLA 100. Duplicates on the gel are derived from control samples, which were frozen before recentrifugation. $\mathrm{K}$ factors were estimated based on $\mathrm{H}_{2} \mathrm{O}$, particles lighter than $1.04 \mathrm{~g} / \mathrm{cm}^{3}$ did not pellet.

\section{Immunofluorescence microscopy}

Cells were grown on coverslips coated with a solution of $5 \mu \mathrm{g} / \mathrm{ml}$ collagen I (with PBS/acetic acid). Immunofluorescence was carried out as previously described [113]. Briefly, coverslips were fixed in $4 \%$ paraformaldehyde in PBS for $20 \mathrm{~min}$ and incubated for $10 \mathrm{~min}$ with $50 \mathrm{mM}$ ammonium chloride. The cells were permeabilized with $0.1 \%$ Triton $\mathrm{X}$ 100 for $4 \mathrm{~min}$ and incubated for $10 \mathrm{~min}$ with $6 \mathrm{M}$ guanidinium- $\mathrm{HCl}$ in $50 \mathrm{mM}$ Tris- $\mathrm{HCl} \mathrm{pH} 7.5$ where indicated [114]. Following two washes in PBS the samples were blocked in 5\% FCS (heat inactivated) in PBS (IFB). All incubations were carried out at r.t. The affinity-purified cav1N14, 'signature' caveolin-1, the ESA and actin antibody were used at a concentration of $33 \mu \mathrm{g} / \mathrm{ml}, 20 \mu \mathrm{g} / \mathrm{ml}, 25 \mu \mathrm{g} / \mathrm{ml}$ and $12.5 \mu \mathrm{g} / \mathrm{ml}$ (IgG1 or total affinity-purified protein), respectively, in IFB. The caveolin-1 polyclonal antibody C13630 was used at a dilution of 1:100 in IFP. Antibodies are defined by these names (see figure legends). The secondary rhodamine and fluorescein conjugated goat anti-rabbit and-mouse antibodies were diluted 1:200 in IFB for the double labeling of caveolin-1 and actin. The secondary fluorescein and $\mathrm{Cy} 3$ conjugated goat anti-rabbit and -mouse antibodies were diluted 1:300 and 1:400, respectively, in IFB for the double labeling of caveolin-1 and ESA (flotillin-2). Single labeling was always carried out with identical dilutions and samples. Photomultiplier amplification was firstly adjusted to control samples incubated in the absence of primary antibodies and, secondly, to single labeled controls to avoid cross talk between channels. Cells were viewed and photographed with an Axiophot (Zeiss) microscope with a video camera or a Leica NT confocal microscope using oil immersion objectives. Confocal sections are as indicated. Pinhole size was 0.16 for the 'signature' antibody, 0.25 for the actin antibody and 0.4 for the ESA antibody experiments. In the jasplakinolide experiments cells were treated with $200 \mathrm{nM}$ jasplakinolide for $60 \mathrm{~min}$ at $37{ }^{\circ} \mathrm{C}$ in MEM. Jasplakinolide was diluted from a $1^{\prime} 000 \times$ stock solution in DMSO.

\section{Acknowledgements}

We thank Thierry Mini for help with mass spectrometric analysis and Helena Bühler, Joachim Scherf and Kitaru Suda for technical support and Nica Borgese for antibodies. The Swiss National Science Foundation and Horten Foundation is thanked for financial support.

\section{References}

1. Davis M.J. and Hill M.A. 1999. Physiol. Rev. 79: 387-423.

2. Kamiya A., Michikami D., Fu Q., Iwase S., Hayano J., Kawada T., Mano T. and Sunagawa K. 2003. Am. J. Physiol. Heart Circ. Physiol. 285: H1158-1167.

3. Palmer R.M.J., Ferrige A.G. and Moncada S. 1987. Nature 327: 524-526.

4. Bucci M., Gratton J.P., Rudic R.D., Acevedo L., Roviezzo F., Cirino G. and Sessa W.C. 2000. Nature Med. 6: 1362-1367.

5. Rizzo V., McIntosh D.P., Oh P. and Schnitzer J.E. 1998. J. Biol. Chem. 273: 34724-34729.

6. Czarny M., Liu J., Oh P. and Schnitzer J.E. 2003. J. Biol. Chem. 278: 4424-4430.

7. Boyd N.L., Park H., Yi H., Boo Y.C., Sorescu G.P., Sykes M. and Jo H. 2003. Am. J. Physiol. Heart Circ. Physiol. 285: H1113-1122.

8. Parat M.-O., Anand-Apte B. and Fox P.L. 2003. Mol. Biol. Cell 14: 3156-3168.

9. Stan R.V., Roberts W.G., Predescu D., Ihida K., Saucan L., Ghitescu L. and Palade G.E. 1997. Mol. Biol. Cell 8: 595605.

10. Oh P. and Schnitzer J.E. 1999. J. Biol. Chem. 274: 23144-54.

11. Oh P. and Schnitzer J.E. 2001. Mol. Biol. Cell 12: 685-98.

12. Simons K. and Toomre D. 2000. Nat. Rev. Mol. Cell Biol. 1: 31-39. 
13. Razani B., Engelman J.A., Wang X.B., Schubert W., Zhang X.L., Marks C.B., Macaluso F., Russell R.G., Li M., Pestell R.G., Di Vizio D., Hou H., Kneitz B., Lagaud G., Christ G.J., Edelman W. and Lisanti M.P. 2001. J. Biol. Chem. 276: 38121-38138.

14. Drab M., Verkade P., Elger M., Kasper M., Lohn M., Lauterbach B., Menne J., Lindschau C., Mende F., Luft F.C., Schedl A., Haller H. and Kurzchalia T.V. 2001. Science 293: 2449-2452.

15. Souto R.P., Vallega G., Wharton J., Vinten J., Tranum-Jensen J. and Pilch P.F. 2003. J. Biol. Chem. 278: 18321-18329.

16. Liu L., Mohammadi K., Aynafshar B., Wang H., Li D., Liu J., Ivanov A.V., Xie Z. and Askari A. 2003. Am. J. Physiol. Cell Physiol. 284: C1550-C1560.

17. Teubl M., Groschner K., Kohlwein S.D., Mayer B. and Schmidt K. 1999. J. Biol. Chem. 274: 29529-35.

18. Bossuyt J., Taylor B.E., James-Kracke M. and Hale C.C. 2002. FEBS Letters 511: 113-7.

19. Agin D. 1972. Excitability phenomena in membranes, in: Rosen, R. (Eds.), Foundations of mathematical biology. Academic Press, New York and London, pp. 253-277.

20. Kurzchalia T.V., Dupree P., Parton R.G., Kellner R., Virta H., Lehnert M. and Simons K. 1992. J. Cell Biol. 118: 10031014.

21. Conrad P.A., Smart E.J., Ying Y.S., Anderson R.G.W. and Bloom G.S. 1995. J. Cell Biol. 131: 1421-1433.

22. Thomsen P., Roepstorff K., Stahlhut M. and van Deurs B. 2002. Mol. Biol. Cell 13: 238-50.

23. Pelkmans L., Puntener D. and Helenius A. 2002. Science 296: 535-9.

24. Parton R.G., Way M., Zorzi N. and Stang E. 1997. J. Cell Biol. 136: 137-54.

25. Hamill O.P. and Martinac B. 2001. Physiol. Rev. 81: 685740.

26. Ernstrom G.G. and Chalfie M. 2002. Annu. Rev. Genet. 36: 411-453.

27. Geiger B. and Bershadsky A. 2001. Curr. Opin. Cell Biol. 13: 584-92.

28. Naruse K. and Sokabe M. 1993. Am. J. Physiol. Cell Physiol. 264: C1037-C1044.

29. Ordway R.W., Walsh J.V., Jr. and Singer J.J. 1989. Science 244: 1176-9.

30. Kim D. and Clapham D.E. 1989. Science 244: 1174-6.

31. Busse R. and Fleming I. 2003. TiPS 24: 24-29.

32. Gudi S., Nolan J.P. and Frangos J.A. 1998. Proc. Natl. Acad. Sci. 95: 2515-9.

33. Smith M.L., Long D.S., Damiano E.R. and Ley K. 2003. Biophys. J. 85: 637-645.

34. Illi B., Nanni S., Scopece A., Farsetti A., Biglioli P., Capogrossi M.C. and Gaetano C. 2003. Circ. Res. 93: 155-61.

35. Moser T.L., Kenan D.J., Ashley T.A., Roy J.A., Goodman M.D., Misra U.K., Cheek D.J. and Pizzo S.V. 2001. Proc. Natl. Acad. Sci. 98: 6656-61

36. Runswick M.J. and Walker J.E. 1983. J. Biol. Chem. 258: 3081-9.

37. Mourier T., Hansen A.J., Willerslev E. and Arctander P. 2001. Mol. Biol. Evol. 18: 1833-1837.

38. Esnault C., Maestre J. and Heidmann T. 2000. Nat. Genet. 24: 363-367.

39. Chittum H.S., Lane W.S., Carlson B.A., Roller P.P., Lung F.D., Lee B.J. and Hatfield D.L. 1998. Biochemistry 37: $10866-70$
40. Moser T.L., Stack M.S., Asplin I., Enghild J.J., Hojrup P., Everitt L., Hubchak S., Schnaper H.W. and Pizzo S.V. 1999. Proc. Natl. Acad. Sci. 96: 2811-6.

41. Martinez L.O., Jacquet S., Esteve J.-P., Rolland C., Cabezon E., Champagne E., Pineau T., Georgeaud V., Walker J.E., Terce F., Collet X., Perret B. and Barbaras R. 2003. Nature 421: 75-79

42. Di Virgilio F., Chiozzi P., Ferrari D., Falzoni S., Sanz J.M., Morelli A., Torboli M., Bolognesi G. and Baricordi O.R. 2001. Blood 97: 587-600.

43. Smalheiser N.R. 1996. Mol. Biol. Cell 7: 1003-14.

44. Nakamura F. and Strittmatter S.M. 1996. Proc. Natl. Acad. Sci. 93: 10465-70.

45. Bodin P. and Burnstock G. 2001. J. Cardiovasc. Pharmacol. 38: $900-8$.

46. Bankston L.A. and Guidotti G. 1996. J. Biol. Chem. 271: 17132-8.

47. Anderson R.G.W. 1993. Proc. Natl. Acad. Sci. 90: 1090910913.

48. Schroeder W.T., Stewart-Galetka S., Mandavilli S., Parry D.A., Goldsmith L. and Duvic M. 1994. J. Biol. Chem. 269: 19983-19991.

49. Bickel P.E., Scherer P.E., Schnitzer J.E., Oh P., Lisanti M.P. and Lodish H.F. 1997. J. Biol. Chem. 272: 13793-13802.

50. Schulte T., Paschke K.A., Laessing U., Lottspeich F. and Stuermer C.A. 1997. Development 124: 577-587.

51. Morrow I.C., Rea S., Martin S., Prior I.A., Prohaska R., Hancock J.F., James D.E. and Parton R.G. 2002. J. Biol. Chem. 277: 48834-48841.

52. Goodman M.B., Ernstrom G.G., Chelur D.S., O’Hagan R., Yao C.A. and Chalfie M. 2002. Nature 415: 1039-42.

53. Lang D.M., Lommel S., Jung M., Ankerhold R., Petrausch B., Laessing U., Wiechers M.F., Plattner H. and Stuermer C.A. 1998. J. Neurobiol. 37: 502-523.

54. Braet F., Spector I., DeZanger R. and Wisse E. 1998. Proc. Natl. Acad. Sci. 95: 13635-13640.

55. Stahlhut M. and vanDeurs B. 2000. Mol. Biol. Cell 11: 325337.

56. Dupree P., Parton R.G., Raposo G., Kurzchalia T.V. and Simons K. 1993. EMBO J. 12: 1597-1605.

57. Nomura R. and Fujimoto T. 1999. Mol. Biol. Cell 10: 975986.

58. Sargiacomo M., Scherer P.E., Tang Z.L., Kubler E., Song K.S., Sanders M.C. and Lisanti M.P. 1995. Proc. Natl. Acad. Sci. 92: 9407-9411.

59. Monier S., Parton R.G., Vogel F., Behlke J., Henske A. and Kurzchalia T.V. 1995. Mol. Biol. Cell 6: 911-927.

60. Volonte D., Galbiati F., Li S., Nishiyama K., Okamoto T. and Lisanti M.P. 1999. J. Biol. Chem. 274: 12702-12709.

61. Berendes R., Voges D., Demange P., Huber R. and Burger A. 1993. Science 262: 427-30.

62. Demange P., Voges D., Benz J., Liemann S., Gottig P., Berendes R., Burger A. and Huber R. 1994. Trends Biochem. Sci. 19: 272-6.

63. Cardo-Vila M., Arap W. and Pasqualini R. 2003. Mol. Cell 11: 1151-62.

64. Andersen M.H., Berglund L., Petersen T.E. and Rasmussen J.T. 2002. Biochem. Biophys. Res. Commun. 292: 550-7.

65. Pietrini G., Carrera P. and Borgese N. 1988. Proc. Natl. Acad. Sci. 85: 7246-50.

66. Borgese N., Aggujaro D., Carrera P., Pietrini G. and Bassetti M. 1996. J. Cell Biol. 135: 1501-13.

67. Anderson R.G.W. 1998. Annu. Rev. Biochem. 67: 199-225. 
68. Liu P., Rudick M. and Anderson R.G.W. 2002. J. Biol. Chem. 277: 41295-41298.

69. Parton R.G. 2003. Nature Rev. Mol. Biol. 4: 162-167.

70. Marchesan D., Rutberg M., Andersson L., Asp L., Larsson T., Boren J., Johansson B.R. and Olofsson S.-O. 2003. J. Biol. Chem. 278: 27293-27300.

71. Li W.P., Liu P.S., Pilcher B.K. and Anderson R.G.W. 2001. J. Cell Sci. 114: 1397-1408.

72. Schlegel A., Schwab R.B., Scherer P.E. and Lisanti M.P. 1999. J. Biol. Chem. 274: 22660-22667.

73. Schlegel A. and Lisanti M.P. 2000. J. Biol. Chem. 275: 21605-21617.

74. Arbuzova A., Wang L., Wang J., Hangyas-Mihalyne G., Murray D., Honig B. and McLaughlin S. 2000. Biochemistry 39: 10330-9.

75. Li S., Okamoto T., Chun M., Sargiacomo M., Casanova J.E., Hansen S.H., Nishimoto I. and Lisanti M.P. 1995. J. Biol. Chem. 270: 15693-15701.

76. Fujimoto T., Nakade S., Miyawaki A., Mikoshiba K. and Ogawa K. 1992. J. Cell Biol. 119: 1507-13.

77. Trouet D., Nilius B., Jacobs A., Remacle C., Droogmans G. and Eggermont J. 1999. J. Physiol. 520: 113-119.

78. Isshiki M., Ying Y.S., Fujita T. and Anderson R.G. 2002. J. Biol. Chem. 277: 43389-43398.

79. Georgievskii Y., Medvedev E.S. and Stuchebrukhov A.A. 2002. Biophys. J. 82: 2833-46.

80. Cherepanov D.A., Feniouk B.A., Junge W. and Mulkidjanian A.Y. 2003. Biophys. J. 85: 1307-1316.

81. Walker J.E., Collinson I.R., Van Raaij M.J. and Runswick M.J. 1995. Methods Enzymol. 260: 163-90.

82. Homolya L., Steinberg T.H. and Boucher R.C. 2000. J. Cell Biol. 150: 1349-1359.

83. Brown D.A. and London E. 1998. Annu. Rev. Cell Dev. Biol. 14: 111-136.

84. Sordella R., Jiang W., Chen G.-C., Curto M. and Settleman J. 2003. Cell 113: 147-158.

85. Roper K., Corbeil D. and Huttner W.B. 2000. Nat. Cell Biol. 2: 582-592.

86. Prior I.A., Parton R.G. and Hancock J.F. 2003. Sci STKE pI9.

87. Brenner R., Perez G.J., Bonev A.D., Eckman D.M., Kosek J.C., Wiler S.W., Patterson A.J., Nelson M.T. and Aldrich R.W. 2000. Nature 407: 870-6.

88. Edwards G., Dora K.A., Gardener M.J., Garland C.J. and Weston A.H. 1998. Nature 396: 269-72.

89. Nilius B. and Droogmans G. 2001. Physiol. Rev. 81: 141559.

90. Schwiebert L.M., Rice W.C., Kudlow B.A., Taylor A.L. and Schwiebert E.M. 2002. Am. J. Physiol. Cell Physiol. 282: C289-301.
91. Zsembery A., Boyce A.T., Liang L., Peti-Peterdi J., Bell P.D. and Schwiebert E.M. 2003. J. Biol. Chem. 278: 1339813408.

92. Schnermann J. and Levine D.Z. 2003. Annu. Rev. Physiol. 65: 501-529.

93. Inscho E.W., Cook A.K. and Navar L.G. 1996. Am. J. Physiol. 271: F1077-85.

94. Megson A.C., Dickenson J.M., Townsend-Nicholson A. and Hill S.J. 1995. Br. J. Pharmacol. 115: 1415-24.

95. Rohra D.K., Saito S.Y. and Ohizumi Y. 2003. Eur. J. Pharmacol. 465: 141-4.

96. Henttinen T., Jalkanen S. and Yegutkin G.G. 2003. J. Biol. Chem. 278: 24888-24895.

97. Wary K.K., Mainiero F., Isakoff S.J., Marcantonio E.E. and Giancotti F.G. 1996. Cell 87: 733-743.

98. Bischofs I.B. and Schwarz U.S. 2003. Proc. Natl. Acad. Sci. 100: 9274-9279.

99. Rogers M.J. and Strittmatter P. 1975. J. Biol. Chem. 250: 5713-8.

100. Oshino N., Imai Y. and Sato R. 1971. J. Biochem. Tokyo. 69: 155-67.

101. Okayasu T., Nagao M., Ishibashi T. and Imai Y. 1981. Arch Biochem. Biophys. 206: 21-8.

102. Ishibashi T. and Bloch K. 1981. J. Biol. Chem. 256: 12962-7.

103. Strittmatter P., Spatz L., Corcoran D., Rogers M.J., Setlow B. and Redline R. 1974. Proc. Natl. Acad. Sci. 71: 4565-9.

104. Cantor R.S. 1999. Chem. Phys. Lipids. 101: 45-56.

105. Megli F.M., Selvaggi M., Liemann S., Quagliariello E. and Huber R. 1998. Biochemistry 37: 10540-6.

106. Razani B., Combs T.P., Wang X.B., Frank P.G., Park D.S., Russell R.G., Li M., Tang B., Jelicks L.A., Scherer P.E. and Lisanti M.P. 2002. J. Biol. Chem. 277: 8635-47.

107. Echevarria W., Leite M.F., Guerra M.T., Zipfel W.R. and Nathanson M.H. 2003. Nat. Cell Biol. 5: 440-6.

108. Jacobson B.S., Schnitzer J.E., McCaffery M. and Palade G.E. 1992. Eur. J. Cell Biol. 58: 296-306.

109. Tunon P. and Johansson K.E. 1984. J. Biochem. Biophys. Methods 9: 171-179.

110. Delbruck R., Desel C., von Figura K. and Hille-Rehfeld A. 1994. Eur. J. Cell Biol. 64: 7-14.

111. Pasquali C., Fialka I. and Huber L.A. 1997. Electrophoresis 18: 2573-81.

112. Yates J.R.d., Eng J.K., McCormack A.L. and Schieltz D. 1995. Anal. Chem. 67: 1426-36.

113. Fiedler K., Parton R.G., Kellner R., Etzold T. and Simons K. 1994. EMBO J. 13: 1729-1740.

114. Peränen J., Rikkonen M. and Kääriäinen L. 1993. J. Histochem. Cytochem. 41: 447-454. 